\title{
Stanisław Chankowski
}

Uniwersytet Warszawski

e-mail: staschankowski@gmail.com

\section{Jak panująca ideologia uniemożliwia przemianę społeczną}

Słowa kluczowe: ideologia, kapitalizm, podmiot, oświecenie, interpelacja, cynizm, Karol Marks, Theodor Adorno, Max Horkheimer, Czesław Miłosz, Louis Althusser, Jacques Lacan, Slavoj Zizek, Peter Sloterdijk, nowoczesność, Odyseusz, rozum instrumentalny, strukturalizm, Karl Mannheim, klasy, praktyka

\section{Wstęp. Ku nowej zagladzie}

Bomba atomowa jest Budda Zachodu, perfekcyjnym, suwerennym mechanizmem bez ograniczeń. [...] Wraz z nia opuszczamy królestwo rozumu praktycznego, gdzie do celu zmierza się za pomoca odpowiednich środków. Bomba już od dawna nie jest środkiem do celu, albowiem jest środkiem nieznajacym miary, przerastajacym każdy możliwy cel. [...] Nie możemy być już bardziej źli, bardziej inteligentni i bardziej defensywni ${ }^{1}$.

Zanik myśli i ideowe zubożenie jest dzisiaj zjawiskiem empirycznie ewidentnym, rozciągniętym powszechnie na wszystkie dziedziny życia społecznego. Chodzi o zanik myśli, która kiedyś ożywiała emancypacyjne zrywy przez ludzi i dla ludzi wzniecane, przez ludzi i dla ludzi obmyślone. I choć wielu z krzątających się na globalnym

\footnotetext{
1 P. Sloterdijk, Krytyka cynicznego rozumu, Wrocław 2008, s. 150.
} 
rynku w rojowisku sobie podobnych pionków, po całodziennym wypełnianiu zadań przepisanych przez ideologiczne check-listy rozwoju osobowości, zgorzkniałych legnie we własnym łóżku z nieśmiałą refleksją, ,jaki sens jest tego, co dzień w dzień przyszło mi robić?", to nie zdobędzie się jednak na jej poważne podjęcie, albowiem podobny przebłysk aktywności krytycznej byłby nieznośnie złowieszczy dla porządku, w którym żyjemy. Czesław Miłosz, który będzie drogowskazem w rozważaniach niniejszego opracowania, komentuje ten stan rzeczy w Zniewolonym umyśle w sposób następujący:

Co zostaje, to wielki wstręt do trwania szczegółu, do tej mentalności, dla której każde zjawisko istnieje osobno: jeść, pić, zarabiać, obłapiać, rodzić dzieci. I co dalej? Czy to powinno trwać? Dlaczego ma trwać? Takie pytanie jest niemal równoznaczne z tym, co nazywa się nienawiścią do burżuazji².

Sama krytyczna refleksja jest więc już dla geologów społecznego status quo tektonicznym pęknięciem, spod którego mogą trysnąć iskry zwiastujące erupcję lawy gwałtownej przemiany. Taka refleksja sama więc przynależy do walki klasowej, skoro utożsamia nienawiść do burżuazji. Toteż wszelkie działania owych geologów wymierzone będą w jej źródło: w umysł człowieka nowoczesnego, by pokornie zajął się pomnażaniem ,światowego dobrobytu”, z którego i tak nie skorzysta, gdyż albo nie pozwoli na to jego wynagrodzenie, a gdyby przypadkiem jednak pozwoliło, uniemożliwi mu to ingerencja sił kapitału w organizację jego pracy, zagospodarowując jego czas. Czasu ni sił mieć więc nie może i mieć ich nie będzie ani na przypatrywanie się, ani użycie tego co wytworzył, ani na myślenie jako takie. Ma on jednak czuć się bezgranicznie wolny i wystarczająco niezależny jako autonomiczny podmiot, by wobec każdego innego, który jest w podobnej sytuacji, czuć chłód rywalizacji i konkurencji, nigdy jednak solidarność. Ta ma pozostać związana z uczuciami, którymi darzyć należy władzę, bowiem tylko tak można indywidualnie zaskarbić sobie jej przychylność i trwać dalej spokojnie w cieniu walącego się gmachu ludzkiego świata.

Jeśli ten gmach runie, będzie to ciekawy powód do ironicznego westchnięcia: społeczeństwa świata wznosiły się raz po raz na wyżyny twórczości, pnąc się ku kolejnym szczeblom cywilizacyjnego rozwoju, czego przykłady zadziwiają niekiedy wynalazczością, innym razem, gdy idzie o ekspresję artystyczną, poruszają najtwardsze serca. Ludzkość wznosiła i wznosi sięgające chmur konstrukcje, lata w kosmos lub pisze wiekopomne dzieła literackie. Wszystko to jest dziełem rąk i myśli, dziełem, którego owoce często z perspektywy społecznych celów są nieuzasadnione i skrajnie niesprawiedliwie rozdzielone, lecz równie często zapierające dech w piersiach. I o to miałaby ludzkość skompromitować się i skończyć pod ciężarem własnego rozwoju.

2 C. Miłosz, Zniewolony umyst, Kraków 2004, s. 20. 
Byłoby to co najmniej groteskowe, jeśli zastanowić się nad tym, patrząc z dystansu i bez sympatii dla ludzkiego gatunku, o co ten ciągle bezmyślnie zabiega. Lecz włos się zjeży, jeśli zdamy sobie sprawę, że tę katastrofę już znamy i wiemy, że nie dotyka ona nigdy wszystkich. Są bowiem wybrańcy, którzy dla swoich wynaleźli już reprodukcyjne serum na śmierć społeczną i fizyczną.

Elity żyjące „na Parnasie”, ciesząc się przywilejami, jakie daje władza nad kapitałem, złożą na ołtarzu nowej zagłady tych, których i tak od wieków potrzebowali tylko dla realizacji własnych interesów, imając się najróżniejszych zracjonalizowanych metod wyzysku. Będzie to wygrana tego zestawu genów dumnie zwanego człowiekiem, której antycypacje już napotykamy na każdym kroku. Wizja ta nasuwa Miłoszowi tezę przepełnioną goryczą: ,jeżeli cały nasz ludzki rodzaj miał do wyboru albo przegrać, albo tak wygrać, jak wygrał, wygrać nie było warto"3.

Stawką dla tych, którzy mają wygrać, jest taka organizacja świata, przy której każda aktywność myśli jest poddana zunifikowanej formie szeregu ideologicznych praktyk życia społecznego. To dzięki uczestnictwu w nich każda jednostka będzie mogła stać się podmiotem zaangażowanym w podtrzymywanie niesprawiedliwego ładu. Piszą o tym francuscy strukturaliści: Louis Althusser, dokonując swojej interpretacji teorii marksistowskiej, i Jacques Lacan, formalistycznie wykorzystując Freuda. Piszą o tym także, choć w zupełnie inny sposób, za pomocą odmiennych pojęć i kategorii, niemieccy luminarze szkoły frankfurckiej Theodor Adorno i Max Horkheimer, którzy badają korzenie oświecenia i powstanie nowoczesnego podmiotu. Na przecięciu prac tych teoretyków i przy inspiracji eseistyczną narracją Miłosza zamierzam prowadzić moje rozważania o panującej ideologii i jej wpływie na możliwość radykalnej przemiany, która wydaje mi się konieczna, jeśli chcemy nie tylko poprawić jakoś bytu niektórych, ale ocalić od zguby większość i dochować wierności dotychczasowym zdobyczom ducha. Utopią jest dzisiaj wiara w drobne korekty, jakiej wymaga liberalna demokracja, podobnie jak dla Włodzimierza Lenina zgubną mrzonką była chęć ocalenia osiągnięć rewolucji lutowej bez jej rewolucyjnego powtórzenia i przekształcenia. ,Jedynym sposobem, by ocalić zdobycze Rewolucji Lutowej (wolność zrzeszania się, prasy i tak dalej), jest przejście do rewolucji socjalistycznej, w przeciwnym razie wygrają carscy reakcjoniści”4. Czyż dzisiaj żądanie zbyt mało nie jest zatem po prostu krokiem wstecz i zdradą ludzkości?

3 C. Miłosz, Góry Parnasu, Warszawa 2012, s. 81.

4 S. Žižek, Rewolucja u bram. Pisma Lenina z 1917 roku, Kraków 2007, s. 42. 


\section{Kapitalizm w aspektach: strukturalnym, antropologicznym i fenomenologicznym}

Marcuse przychodzi i powiada: „Dzieje się tak ponieważ jesteście w niewoli. Tyrania, która was uciska, nie ma ukrytych w jakiś pałacach czy zamkach ośrodków dyspozycyjnych, nikt jej nie zaplanowat, nie potrzebuje też ona uciekać się do rozkazów i zakazów.

A przecież kontrola, jaka sprawuje nad wami, jest całkowita, bo jesteście całkowicie przekształceni od środka, wasz umyst, wasze emocje, wasze pragnienia nie do was przynależa, są narzucone przez nia, mistrzynię społecznego obrzędu”.

Chciałbym, by punktem wyjścia moich rozważań był kapitalizm rozumiany na sposób marksowski, jako historyczna forma produkcji i jej warunków. Za słuszną przyjmę także metodę i aksjologię teorio-społeczną Karola Marksa głoszącą uzależnienie postępu dziejów ludzkości i zaistniałych form produkcji właśnie, w największym stopniu określających stosunki społeczne, a w konsekwencji ponieważ konstrukcja każdego poszczególnego człowieka jest ich całokształtem, także jednostkę.

Charakter historyczny społeczeństwa jest zatem według Karola Marksa określony przez praktykę wykonywanej w nim pracy wytwórczej, podział i dystrybucję jej produktu czy inaczej - stosunek własności. „Jak osobniki życie swe uzewnętrzniają takie są - powiada ów filozof - To, czym one są, zbiega się zatem z ich produkcją, zarówno z tym, co wytwarzają, jak i z tym, jak wytwarzają. A więc to, czym osobniki są, zależy od materialistycznych warunków ich produkcji”'. I dalej opisuje, jak podział pracy określa stosunki grup ją wykonujących i charakter kolejnych etapów historii:

Podział pracy wewnątrz jakiegoś narodu prowadzi zarazem do oddzielenia się pracy przemysłowej i handlowej od rolniczej, a przez to do oddzielenia się miasta od wsi oraz przeciwstawności ich interesów. [...] Jednocześnie, na skutek podziału pracy wewnątrz tych gałęzi, powstają z kolei rozmaite grupy osobników współdziałających w określonych pracach. Wzajemny stosunek tych poszczególnych grup warunkowany bywa sposobem wykonywania pracy rolniczej, przemysłowej i handlowej (patriarchalizm, niewolnictwo, stany, klasy) ${ }^{7}$.

Kapitalizm, który przyjmuję za podstawową przesłankę mojej pracy, postrzegał Marks jako system pracy wytwórczej, który opiera się na antagonizmie dzielącym klasę robotniczą i kapitalistów: zawężającą się grupę posiadaczy czerpiących zyski

5 C. Miłosz, Widzenia nad Zatoka San Francisco, Paryż 1980, s. 144.

6 K. Marks, Pisma wybrane, Warszawa 1979, s. 236.

7 Ibidem, s. 237. 
z pracy najemnej i robotników zmuszonych do sprzedaży swej siły roboczej. Uniwersalnym prawem gospodarki kapitalistycznej jest dążenie do maksymalnego zysku osiąganego przez sprzedaż towarów na wciąż rozrastającym się (tak pod względem rozszerzającego się terytorium, jak i rosnącej stale ilości towarów) rynku. Wartość towarowa produktu składa się z części przeznaczonej na odnowienie kapitału stałego (środków produkcji, surowców), wartości dodanej zagarnianej przez kapitalistę koncentrującego coraz większy kapitał i płacy roboczej malejącej wraz z udziałem robotnika w procesie produkcji, co powodowane jest stałym rozwojem technologicznym środków produkcji. Prowadzi to do pauperyzacji proletariatu i zaostrzenia antagonizmów klasowych.

Ponadto robotnik, pracując przy użyciu niebędących jego własnością środków produkcji, wytwarzając produkty, które do niego nie należą, otrzymuje płacę, która nie pozwala mu na godny byt, toteż praca przez niego wykonywana przestaje być źródłem jego samorealizacji i staje się wyalienowana, narzucona i przymuszona. Dodatkowo przedmioty wytwarzane przezeń, wchodząc na rynek, zyskują wartość wymienną wyrażoną $\mathrm{w}$ abstrakcyjnej wartości pieniądza, sprawiając, że stosunki produkcji i w ogóle stosunki społeczne zostają urzeczowione i zapanowują nad światem ludzi, a zwłaszcza nad klasą robotniczą. Dlatego kapitalizm ze swej istoty będzie miał zawsze dwa oblicza: jedno konkretne - bezwzględnego wyzyskiwacza i drugie abstrakcyjnej oraz alienującej miary wartości.

Powyżej nakreśliłem roboczo naturę kapitalizmu jako społecznej bazy, tak jak określiłaby to teoria marksowska. Chciałbym teraz podjąć pytanie o to, jakie konsekwencje taka struktura pracy i system relacji społecznych zogniskowanych wokół historycznych warunków bytu ludzkiego niesie dla tego, co możemy nazwać świadomością lub osobowością kapitalistyczną. I zwrotnie: tak jak z tej struktury wynika konstrukcja osobowości i jej świadomość, tak zajmujące jest pytanie, jakie konsekwencje dla sposobu produkcji ma ideologia czy żywione przez ludzi przekonania. Gdy zechcemy bowiem poznać motywacje współczesnego człowieka, jego wyobrażenia o sobie samym i otaczającym świecie, gdy przedmiotem naszego zainteresowania stanie się natura relacji, które zakorzeniają go w jego środowisku, spostrzeżemy, że podstawową prawdą jest właśnie kapitalizm

Pytaniem przewodnim niniejszego opracowania jest to, jak kapitalizm jawi się w oczach podporządkowanych mu podmiotów. Starałem się w sposób uproszczony przedstawić obiektywny obraz kapitalizmu, a także przez pojęcie alienacji - jego an-

8 Można postawić oczywiście tutaj zarzut o monistyczną tendencję powodującą, że doszukuję się w heterogeniczności świata zjawisk jednej zasady sprawczej, która organizuje całość. Nawet jeżeli występują jeszcze jakieś przejawy życia wyłączone spod kapitalistycznej logiki, to jej ekspansywna natura dąży do włączenia także i tych. Na tym polega u Marksa subsumpcja realna, dzięki której towarem staje się nie tylko siła robocza, ale również wszystkie przejawy społecznego życia jednostki, dla której granicą jest już tylko samo nagie życie. 
tropologiczny wymiar. Lecz czym innym jest jego subiektywne doświadczenie, czyli jego wymiar fenomenologiczny, przeżywanie go jako rzeczywistości danej ludzkim podmiotom, oraz sposób przeżywania tej podmiotowości. Marks w Tezach o Feuerbachu stawia zarzut panującemu w jego czasach materializmowi, że „przedmiot, rzeczywistość, zmysłowość, ujmował on jedynie w formie obiektu, nie zaś jako ludzką działalność zmysłową, praktykę, nie subiektywnie"9. Przekonuje tym samym, że poznanie ludzkie nie jest działalnością teoretyczną, ale zagadnieniem praktycznym i w praktyce zakorzenionym. Jeżeli zaś praktyka ta jest społeczna i historyczna, to również poznanie ma taki charakter. Ta obserwacja jest fundamentalnym odkryciem dla nauk społecznych oraz humanistycznych i pozwala rozpocząc badania nad tym, co nazywamy ideologią, zwaną niekiedy społeczną nadbudową. Pisze o niej Marks w przedmowie do Przyczynku do krytyki ekonomii politycznej: „wraz ze zmianą podłoża ekonomicznego odbywa się mniej lub bardziej szybko przewrót w całej olbrzymiej nadbudowie"10.

\section{Bytowe zakorzenienie wiedzy. Karl Mannheim i program socjologii wiedzy}

Ci angielscy psychologowie, którym zawdzięczamy jedyna dotychczas próbę nakreślenia dziejów powstania moralności

- sami sq dla nas niemata zagadka; muszę wyznać, że jako ucieleśniona zagadka istotnie przewyższają swe książki - sami sa interesujacy! ${ }^{11}$

Poczynając od marksowskiego odkrycia, można zacząć od nowa badać społeczną świadomość. Ten problem podejmie w pierwszych dekadach XX wieku Karl Manneheim, który dzięki książce Ideologia $i$ utopia stał się pionierem socjologii wiedzy. Twierdzi on, że „ponieważ w nowoczesnych demokracjach idee reprezentują wyraźnie określone grupy, łatwiej uwidoczniał się w dyskusji politycznej społeczny i bytowy charakter myślenia" ${ }^{12}$. Toteż programem socjologii wiedzy jest badanie bytowych korzeni myślenia. Według Mannheima to właśnie powstanie nowoczesnej polityki i jej powiązanie z nauką umożliwiło podjęcie zadania odsłaniania nieświadomych motywacji zbiorowego myślenia i działania. W pole widzenia członków grupy nie dostają się wszystkie aspekty świata, lecz przede wszystkim te, z których dla grupy

\footnotetext{
9 K. Marks, Pisma wybrane, s. 224.

10 Ibidem, s. 501.

11 F. Nietzsche, Z genealogii moralności, Kraków 2011, s. 17.

12 K. Mannheim, Ideologia i utopia, Warszawa 2008, s. 69.
} 
wynikają jakieś trudności i problemy ${ }^{13}$. Takim podstawowym problemem jest przetrwanie i społeczna reprodukcja warunków bytowych, alokacja produktów i podział pracy prowadzącej do ich wytwarzania. Widać tu wyraźne zadłużenie Mannheima wobec rozpoznań Marksa.

Nim jednak Mannheim przejdzie do tej konkluzji, stara się na kartach swego starannie usystematyzowanego eseju prześledzić historyczne zmiany zachodzące w teorii poznania. Geneza ideologii rozpoczyna się od rozpadu obiektywnego świata dogmatycznie założonego, który da się opisać jednym systemem ontologicznym, momentu, gdy uwaga myślicieli zwróciła się w stronę analizy myślącego i poznającego podmiotu. Każda bowiem wcześniejsza spekulacja teoriopoznawcza - przypomina niemiecki socjolog - oparta była na dychotomii podmiot-przedmiot. Analiza zapośredniczona przez transcendentalny i pozazmysłowy podmiot ustąpiła następnie miejsca metodzie empirycznej i genetycznej badającej psychologiczną strukturę poznawczą tegoż podmiotu. Założenie tkwiące u podstaw tej tendencji było takie, że doświadczenie wewnętrzne dane jest bardziej bezpośrednio niż doświadczenie zewnętrzne. Starano się w ten sposób nieudolnie uniknąc pytań ontologicznych, zastępując je rozpoznaniami kognitywnymi. Nieudolnie dlatego, że poddana badaniom psyche wraz ze swoimi przeżyciami jest przecież także elementem rzeczywistości, „wiedza zaś o tych przeżyciach zakłada jakąś teorię rzeczywistości, czyli ontologię"14. W niedługim czasie przyrodnicza i mechanicystyczna aparatura pojęciowa (posługująca się kategoriami położenia, ruchu, przyczyny, skutku) została przeniesiona na introspekcyjne zabiegi poznawcze, dokonując ich formalizacji. Doświadczenie wewnętrzne poczęto opisywać takimi kategoriami, jak strach, konflikty wewnętrzne, przeżycie izolacji, libido. Fenomeny psychiczne stały się również funkcjonalne wobec całego systemu.

Tej mechanicystycznej metodzie Mannheim zarzuca, że nie wyjaśnia ukrytego pod fenomenami psychicznymi sensu, i przeciwstawia jej metodę psychogenetyczną, której zaleta polega na tym, że stawia pytanie o kontekst zewnętrzny wobec samych przeżyć, w świetle którego należy interpretować poszczególne stany psychiczne.

Jak wynika z wywodu Mannheima, skupianie się na wiedzy i stanach psychicznych jednostki było zaniedbaniem, które musiała korygować socjologia, by przezwyciężyć fikcyjne przekonanie, że o jednostce można mówić w oderwaniu od grupy. „Wiedza - mówi on - jest od samego początku kooperatywnym procesem grupowy$\mathrm{m}^{\prime \prime 15}$. Z tego zarysu historii poznania wyłania się istotny dla nas problem ideologii.

Pojęcie ideologii (choć znane jest już wcześniej) zrodziło się z fundamentalnej podejrzliwości wobec świata zjawisk, do interpretacji których potrzeba solidnej teo-

\footnotetext{
13 Ibidem, s. 59.

14 Ibidem, s. 46.

15 Ibidem, s. 50.
} 
rii. W ciągu stulecia poprzedzającego wybuch II wojny światowej mają miejsce trzy próby przekroczenia warstwy postrzeganych faktów i sięgnięcia do ich nieuświadomionej, nadającej im znaczenie struktury. Autorami dwóch pierwszych są Zygmunt Freud i Fryderyk Nietzsche. Trzecią była Marksa teoria ideologii. Ona właśnie najbardziej będzie mnie zajmować w tym opracowaniu, choć zamierzam też zwrócić uwagę na to, jak teoria ta $\mathrm{w}$ dalszych stadiach swojego rozwoju spotkała się z psychoanalizą Freuda. Mannheim pisze, że „w słowie «ideologia» tkwi implicite pogląd, że w określonych sytuacjach zbiorowa nieświadomość pewnych grup zaciemnia zarówno im samym, jak i innym rzeczywistą sytuację społeczeństwa i działa przez to stabilizująco”16. Jeśli zatem ideologię ogólnie zdefiniujemy jako „fałszywą świadomość”, która zniekształca czy wręcz zakrywa realne stosunki społeczne i prawdę o nich, będziemy mogli, przyjmując i korzystając z rozróżnień i systematyzacji obecnych w Ideologii i utopii, mieć cały czas w horyzoncie myślenia marksowskie rozpoznania.

Mannheim czyni ważne rozróżnienie na ideologię będącą zafałszowaniem rzeczywistości w służbie czyichś interesów, na przykład klasowych burżuazji, oraz taką, która jest pewnym obowiązującym paradygmatem, noologicznym - jak to określa systemem rozumienia rzeczywistości.

Ich cechą wspólną jest to, że „próbują one ująć zamierzoną treść (idee przeciwnika) nie poprzez bezpośrednie rozumiejące zagłębianie się w wypowiedzi [...], lecz na drodze okrężnego rozumienia owego zbiorczego lub indywidualnego podmiotu, który wypowiada te idee i do którego sytuacji bytowej następnie funkcjonalizujemy te idee" $"$.

Pierwszy wyróżniony przez Mannheima typ ideologii jest świadomym bądź nieuświadomionym kreowaniem społecznych wyobrażeń o rzeczywistości w celu jej zafałszowania i stworzenia pozorów przemawiających za utrzymaniem status quo, obecnego stanu rzeczy, który służy określonym interesom. Typ ten nazywa on partykularnym. „Może tu wchodzić w grę cała skala od świadomego kłamstwa do półświadomego, instynktownego maskowania, od oszukiwania innych do oszukiwania samego siebie"18. Jej krytyka może zatem służyć jako świetne narzędzie dyskredytacji przeciwnika w dyskursie: zarzucić komuś, że celowo skrywa logiką wywodu i argumentacji własne interesy, i udowodnić to oznacza odnieść nad nim miażdżące zwycięstwo. Dzisiaj można tego rodzaju ideologii doszukiwać się na przykład w reklamowych kampaniach i technikach marketingowych.

Drugi typ ideologii nazywa Mannheim totalnym lub radykalnym. Jest on całościowym postrzeganiem świata właściwym jakiejś epoce lub określonej społeczno-historycznie klasie czy grupie. Stanowi strukturę świadomości właściwą dla danego

\footnotetext{
16 Ibidem, s. 70.

17 Ibidem, s. 91.

18 Ibidem, s. 90.
} 
kontekstu ${ }^{19}$. Jako wytwór określonego społeczeństwa jest totalnym światopoglądem obejmującym zespół obowiązujących kategorii poznawczych. Jest on sposobem odbierania rzeczywistości właściwym danemu momentowi historycznemu.

Te dwa rodzaje rozumienia ideologii mogą się ze sobą splatać i mieszać; te same fakty obecne w świadomości zbiorowej można przypisywać i rozumieć często zarazem jako elementy ideologii partykularnej i totalnej.

Rozpatrzmy wstępnie przykład ideologii występującej w przemysłowym kapitalizmie w nowoczesnej demokracji. Z jednej strony wydaje się, że ta forma ustroju państwa i organizacji społecznej jest emanacją rozumianej w znaczeniu totalnym ideologii, która odwołując się do idei oświeceniowego humanizmu, przyznaje każdej jednostce cały zakres gwarantowanych wolności osobistych, politycznej podmiotowości i równości. W demokracji takiej obowiązuje pewien paradygmat będący systemem rozumienia rzeczywistości, na którym opiera się ciesząca się rzekomo powszechną akceptacją umowa społeczna. $Z$ drugiej strony sama równość polityczna bez jej społecznego, materialnego czy bytowego dopełnienia odpowiadającego warunkom produkcji będzie tylko martwą literą i pustą formą, co de facto podważa powszechną obowiązywalność samej tej formy: kto włada w królestwie produkcji, zasiada po prawicy w prawomocnym niebie parlamentaryzmu. Także aparat pojęciowy nauk, wśród których świetny przykład stanowi ekonomia, posiada w ramach wspomnianego paradygmatu status uniwersalny, choć legitymizuje wcale nie bezstronną ekonomię polityczną. Dlatego właśnie ideologii tej można też przypisać znaczenie partykularne, gdyż swoim etycznym majestatem wspiera i zasłania wyzysk jednych przez drugich. Ideologią o podwójnym znaczeniu miała być też ta niesiona i rozkolportowana przez robotniczą awangardę. Interesem uciskanej klasy robotniczej miało być zrewolucjonizowanie świata, nadanie mu nowej matrycy poznawczej i światopoglądowej. Ta ideologia, podobnie jak burżuazyjna w swoim wczesnym okresie, czerpała uniwersalistyczną siłę ze stojących za nią partykularnych interesów.

Cóż złego w takiej ideologii? Czytaliśmy już przecież: „wraz ze zmianą podłoża ekonomicznego odbywa się mniej lub bardziej szybko przewrót w całej olbrzymiej nadbudowie" ${ }^{20}$. Wedle rozpowszechnionej interpretacji Marksa, którego teoretyczny korpus chce traktować z najwyższą powagą i uznaniem, forma jest tylko epifenomenem bazy, pianą kauzalną wtórną wobec rwących mocą immanentnej konieczności nurtów produkcji. Owszem, w danym momencie historycznym stanowi ich ramy; zaczną one wszelako trzeszczeć pod naciskiem konsekwentnego rozwoju sił produkcyjnych, zaogniania klasowego antagonizmu i zostaną rozerwane, skoro tylko rozwój bazy upomni się o nowe. Te nowe ramy, nowa forma, miałyby przynieść rzeczywiste upowszechnienie szczęścia, zniesienie wyzysku, równość wszystkich istot ludzkich,

19 Ibidem, s. 91.

20 K. Marks, Pisma wybrane, s. 501. 
a stanie się to wkrótce - wieścił sławny niemiecki filozof wraz z synem fabrykanta. Był rok 1848. Po ponad stu pięćdziesięciu latach od ogłoszenia kultowego wręcz Manifestu, po tragicznych zawirowaniach dziejowych, nastaniu i zmierzchu ,Wieku ideologii" niezmiennie dominują bezwstydnie niesprawiedliwe stosunki społeczne. Kapitalizm miał nie zdzierżyć własnej produktywności, a kryzys miał być jego drugą naturą, ale okazał się feniksem, który odradza się ze swoich popiołów. Dlaczego się tak stało?

W moim opracowaniu chciałbym przekonać, że w pewnym sensie odwrotnie, niż sądził Marks, to ideologia kapitalistyczna uniemożliwia dzisiaj przekształcenie materialnej bazy społecznej. Z pola widzenia w niebyt odeszła idea klasowego oporu przeciw kapitalizmowi oraz wyzyskowi; zastąpiona została ona przez zuniwersalizowany i zataczający coraz szersze kręgi wzorzec osobowości kapitalistycznej. Podmiotowi ukształtowanemu według tego wzorca ani w głowie walka o lepszy, szczęśliwszy i sprawiedliwszy świat.

Aby to zrozumieć, należy sięgnąć aż do początków nowoczesności, gdzie kuźnią tej nowej podmiotowości była przemocowa logika przyrody i metoda przetrwania w jej warunkach.

\section{Oświecenie, czyli praktyka kapitalistycznego podmiotu}

Mimo że wiedza techniczna rozszerza horyzont myślenia i działania, ewidentnie zanika autonomia jednostkowego podmiotu, jego zdolność stawienia oporu rozrastającemu się aparatowi masowej manipulacji, siła jego fantazji, niezależny osad. Progresywnemu rozwojowi środków technicznych towarzyszy proces odczłowieczania. Istnieje groźba, że postęp zniweczy cel, który ma urzeczywistnić - ideę człowieka ${ }^{21}$.

Zasada, z której wyłania się nowoczesna podmiotowość kapitalistyczna, jest narzędziem służącym do pozbycia się strachu i zapanowania nad światem. Jej skuteczne stosowanie jest cenzurką dojrzałości wystawioną człowiekowi przez idee oświecenia, rozumiane jako dążność do uwolnienia tegoż człowieka od mitu i uczynienia go panem dzięki jednoznacznie przyjętej naukowej metodzie ${ }^{22}$. Aby ocalić człowieka od nieprzewidywalnej w skutkach gry z nieobliczalnym mitem, naprzód trzeba odczarować świat: uczynić go poznawczo przejrzystym i redukowalnym do jednolitej, nadrzędnej miary. „Logika formalna była wielką szkołą ujednolicania. Podsunęła oświeceniu schemat obliczalności świata. [...] liczba stała się kanonem oświecenia.

21 M. Horkheimer, Krytyka instrumentalnego rozumu, Warszawa 2007, s. 34.

22 M. Horheimer, T.W. Adorno, Dialektyka Oświecenia, Warszawa 2010, s. 15. 
Aby intelekt mógł rozkazywać odczarowanej naturze, musi zdobyć o niej wiedzę"23. Wszystko, co oświecenie spotyka na swojej drodze, segreguje i liczy lub odrzuca, skoro tylko okaże się bezużyteczne. Zamiast krytycznie lub celowego nastawionego intelektu hegemonię w odczarowanym świecie zdobywa rozum racjonalno-instrumentalny. Adorno i Horkheimer, zastanawiając się nad naturą i konsekwencjami oświecenia, przekonują, że wiedza już „nie zmierza do wykształcenia pojęć ni obrazów, nie przyświeca jej chęć poznania, jej celem jest metoda: wykorzystanie cudzej pracy, kapitał"24. Użyteczność techniki będzie jedynym medium między człowiekiem a naturą. „Ludzie chcą od natury nauczyć się jednego: jak jej użyć, by w pełni zapanować nad nią i nad ludźmi” ${ }^{25}$ - stwierdzają założyciele szkoły krytycznej. - „Ludzie płacą za pomnażanie swojej władzy wyobcowaniem od tego, nad czym władzę sprawują. Oświecenie poczyna sobie wobec rzeczy, jak dyktator wobec ludzi. Dyktator zna ludzi o tyle, o ile może nimi manipulować. Człowiek nauki zna rzeczy o tyle, o ile może je zrobić" ${ }^{26}$. W oświeceniu samo poznanie jest albo synonimem władzy ${ }^{27}$, albo nie ma go w ogóle.

Warunkiem koniecznym przyjęcia takiego systemu jest wytworzenie w podmiocie własnej jaźni, która zapanuje nad przygodnymi stanami, następnie zaś nad światem przedmiotów. Pierwotne źródło jaźni, konstruktywnej samowiedzy, występuje już w pogańskich praktykach religijnych, których celem było przekupienie bóstwa ofiarą.

Ofiara ma być zadośćuczynieniem za przelaną krew [...] i spowodować zaniechanie. Zarazem jednak w gościńcu zaznacza się zasada ekwiwalentu: gospodarz otrzymuje realną lub symboliczną równowartość swych świadczeń, gość - prowiant na drogę, który zasadniczo umożliwia mu dotarcie do domu. Jeżeli nawet gospodarz nie przyjmuje bezpośredniej zapłaty, może w każdym razie liczyć na to, że pewnego dnia on sam lub jego krewni będą tak samo podejmowani: jako ofiara złożona bóstwom żywiołów gościniec jest jednocześnie rudymentarnym zabezpieczeniem przed nimi ${ }^{28}$.

Następnie autorzy Dialektyki przywołują antyczną epopeję Homera - Odyseję, aby w jej bohaterze dostrzec i zidentyfikować ,prototyp mieszczańskiego indywi-

\footnotetext{
23 Ibidem, s. 19.

24 Ibidem, s. 21.

25 Ibidem, s. 16.

26 Ibidem, s. 21.

27 Ibidem, s. 16.

28 Ibidem, s. 57.
} 
duum" ${ }^{29}$. Ta figura powstaje właśnie „z owej jednolitej samowiedzy”30. Dla Adorna i Horkheimera Odyseusz jest indywiduum, które wyłania się z pierwotnej otchłani, w której rządzi zmienny los i mit. Jednostka nie jest w niej jeszcze spójnym podmiotem, ale zespołem stanów psychologicznych zależnych od przygód, których jest uczestnikiem. Musi dopiero ukształtować swoją jaźń i zdobyć samowiedzę. „Opozycja między trwającym w czasie Ja a odmianami losu znamionuje opozycję między oświeceniem a mitem. [...] podróż z Troi do Itaki to droga jaźni przez mity - jaźni cieleśnie nieskończenie słabej wobec potęgi przyrody i dopiero formułującej swoją samowiedzę" ${ }^{\prime 1}$. Samowiedza ta kształtuje się wraz z kolejnymi przygodami bohatera, ale jest również konieczna do ich przetrwania. Warto zaznaczyć, że sama formuła epopei scalającej w jedną opowieść wiele mitycznych wydarzeń oddaje to, że:

Prosta nieprawdziwość mitów - fakt, że morze i ziemia naprawdę nie są zamieszkane przez demony - magiczna złuda i niejasność tradycyjnej religii ludowej stają się w perspektywie dojrzałego podróżnika „błądzeniem” wobec jednoznacznego celu, jakim jest samozachowanie, powrót do ojczyzny i trwałej własności ${ }^{32}$.

Tułacz Odyseusz, zmagając z się demonami antycznego świata, osiąga samowiedzę, konstytuuje własną jaźń i zapanowuje nad sobą: ,jaźń nie stanowi sztywnej opozycji wobec przygody, ale właśnie przez tę opozycję formułuje się i przybiera stały kształt, jest jednością w wielości tego, co jej przeczy"333. Istnieje tu jednak pewna istotna sprzeczność:

Panowanie człowieka nad sobą - na czym zasadza się jaźń - jest wirtualnie zawsze destrukcją podmiotu, w którego służbie się dokonuje, gdyż opanowana, uciśniona i rozbita przez samozachowanie substancja to przecież nic innego jak życie, jedyny i determinujący układ odniesienia dla zabiegów samozachowawczych, które są jego funkcją, właśnie to, co ma być zachowane ${ }^{34}$.

Samodzielna jaźń dzięki samodyscyplinie pozwala ujść z życiem przed czyhającymi zagrożeniami i zaznaczyć panowanie nad światem rzeczy. Tak ocalała jednostka jest dla Adorna i Horkheimera prawzorem indywiduum burżuazyjnego. Sama jednak doznaje ona szkody, gdyż musi zrezygnować z własnych konstytuujących ją

\footnotetext{
29 Ibidem, s. 52.

30 Ibidem.

31 Ibidem, s. 55.

32 Ibidem.

33 Ibidem.

34 Ibidem, s. 62.
} 
przeżyć, poddać się autorepresji. Do podobnych wniosków dochodzi Miłosz, rozmyślając nad relacją cnoty i samodyscypliny w warunkach walki z przyrodą i pomiędzy ludźmi, które właśnie za ich sprawą przyjmowały postać najbardziej bezlitosnych. „Represja: w imię zaspokojenia jutro tego, co odczuwam jako moją potrzebę, odmawiać sobie zaspokojenia potrzeby dzisiaj. [...] Czyli zamiast cieszyć się dniem wolnym od pracy, wpadam na pomysł, że ten dzień poświęcę na wykucie narzędzia, które jutro uczyni moją pracę lżejszą"35.

Scalone mity przeżyte przez podmiot stają się powieścią, tak samo poszczególne stany psychologiczne odpowiadające tym mitom, dzięki ofierze zadającej uszczerbek jaźni kształtują ją i zradzają. Ten nowy podmiot, który Adorno i Horkheimer nazwą indywiduum burżuazyjnym, stanie się tworzywem kapitalizmu. Adaptacja innych do tego wzorca wyzwoli niespotykane dotąd w historii siły produkcyjne. Burżuazja nie jest jedyną klasą, która liczyła się w świecie, ale to ona nadała światu nowy bieg, przestawiając życie społeczne i relacje międzyludzkie na nowe tory. Od tego czasu społeczeństwa pędzą po ekspresowych szynach, których kierunek opisali najlepiej Marks i Engels w doniosłym manifeście:

Burżuazja nie może istnieć bez nieustannego rewolucjonizowania narzędzi produkcji, a więc stosunków produkcji, a więc całokształtu stosunków społecznych. Natomiast pierwszym warunkiem istnienia wszystkich dawniejszych klas przemysłowych było zachowanie bez zmian starego sposobu produkcji. [...] Potrzeba coraz szerszego zbytu dla jej produktów gna burżuazję po całej kuli ziemskiej. Wszędzie musi się ona zagnieździć, wszędzie zadomowić, wszędzie zadzierzgnąć stosunki ${ }^{36}$.

Idąc dalej tropem Horkheimera i Adorna, odkrywamy przyszłość i szersze znaczenie ofiary, którą składa bohater Odysei, aby ujść cało z życiem i odnaleźć bezpieczną przystań domowych stron. Odyseusz w punkcie wyjścia, w chwili poprzedzającej konfrontację z kapryśnym losem, chwili, która antycypuje już następne wydarzenia i przepowiada walkę ze sobą i światem, w tym momencie jest on na razie bezradny wobec samotności, z jaką przychodzi mu pokonywać przeciwności. Jego los zależy od humoru morza i wiatrów, a każda niespodziewana mitologiczna przygoda, w której ugrzęźnie, dybie na jego oderwane i jednostkowe życie. Lecz każda przygoda daje możliwość przezwyciężenia siebie i zapanowania wyższej jaźni nad światem chaosu. Toteż wszelka wygrana, która pozwoli ocalić życie, przysporzy satysfakcji znanej każdemu zdobywcy, któremu powiodło się podczas łupieżczej wyprawy. Nawet jeśli Odyseusz przekroczyłby próg własnego domostwa z pustymi rękami i choćby nie

35 C. Miłosz, Widzenia nad Zatoka..., s. 122.

36 K. Marks, F. Engels, Manifest Partii Komunistycznej, w: Dzieła, t. IV, Warszawa 1962, s. $517-$ 518. 
pozostawił w krainach, w których będą miały miejsce jego bohaterskie zmagania, żadnego swojego namiestnika i nawet jeśli formalnie i fizycznie ziemie, po których przyjdzie mu stąpać i przez które będzie uciekać, szukając schronienia, wciąż do niego nie będą należeć i choćby sukcesji króla Itaki nie rozszerzono po tych dziesięciu latach choćby o krok, Odyseusz będzie mógł dumnie powiedzieć: „zdobyte!”. Liczy się bowiem metoda, która w starciu z rzeczywistością odnosi sukces; z niej, kiedy tylko zechce, tułacz będzie mógł skorzystać. Wiedziony rządzą prawdziwych zdobyczy sięgnie wtenczas jak po niezawodną broń, by ujarzmić świat. A zrobi to z pewnością, i to niechybnie.

\section{Odyseusz biznesu: aktualizacja kontekstu}

Obojętność wobec jakiejś określonej formy pracy odpowiada formie spoteczeństwa, w której indywidua z łatwościa przechodza z jednej pracy do drugiej, a wykonywany przez nie określony rodzaj pracy jest dla nich dzietem przypadku i dlatego jest im obojętny ${ }^{37}$.

Podobnie dzisiaj nowoczesna jaźń przebiega przez kolejne doświadczenia stażu i praktyk zawodowych, by wspiąć się wreszcie, poznawszy wszystkie mechanizmy gry rynkowej, na szczyt hierarchii społeczno-ekonomicznej. Ekonomicznej, bo dzięki metodzie, w końcu zaprzęgniętej przez instrumentalny rozum, odbiera należny zysk. Społecznej, bo zyska szacunek i uznanie pośród reszty podobnych sobie indywiduów zachwyconych taką „dobrą robotą", szanujących przede wszystkim „uczciwie” zarobione pieniądze. Tak właśnie objawia się nam ideologia późnego kapitalizmu w swej totalnej postaci i wykreowana przez nią kapitalistyczna osobowość. Klasowe antagonizmy uległy pozornemu rozkładowi, bo oto teraz każdy może zbudować pomnik swej niezależności i dostatku.

Bohater Odysei podejmuje działanie, którego celem jest jego własne przetrwanie. Działając samotnie, walcząc o nie, kwantyfikuje i instrumentalizuje całą otaczającą go rzeczywistość, zaogniając jej źródłowy antagonizm. Jeżeli natura rządzi się logiką siły i przeciwieństw, to Odyseusz tę logikę wzmacnia, przeciwstawiając jedne przedmioty drugim, towarzyszy tułaczki rdzennym mieszkańcom odwiedzanych krain. Aby wyjść samemu obronną ręką, narzędzia i instrumenty sukcesu poddaje chłodnej kalkulacji, a zalicza do nich cały świat przyrody i innych ludzi. Natura ze swoim drapieżnym instynktem jest przy nim łagodną owcą: nie zbudowałaby Auschwitz. Każda złożona przez króla Itaki ofiara będzie moralnie uprawomocniona ryzykiem

37 S. Žižek, Rewolucja u bram..., s. 393. 
niepowodzenia, jakie przyjmuje. Co wie on o świecie? Wie to, że musi przeżyć. Jakie jest jedyne kryterium oceny działań? Skuteczność i optymalizacja strat i korzyści. Jakie działania najlepiej spełniają to kryterium? Oparte na wyzysku ludzi i przyrody.

Autorzy Dialektyki rozpoznają w tej narracji założenia, na których opiera się kapitalistyczna gospodarka. Walczący w pojedynkę o przetrwanie Odyseusz to już nie tylko bohater epopei, ale prefiguracja homo oeconomicus, który dzisiaj przemierza morza rynków, płynie po powierzchni, samodzielnie sterując swoją galerą kariery. Nabywa kolejnych doświadczeń, dzięki zmaterializowanej już w technologii wiedzy omija głębiny. Jest przy tym osobą w najwyższym stopniu towarzyską, przystosowaną społecznie - posiada liczne umiejętności komunikacji interpersonalnej (kapitał społeczny), umie w każdym zjednać sobie przyjaciela, jeśli będzie tego wymagał zysk doraźny lub taki, który ledwie mieni się w oddali czasu, nawet ten, którego w ogóle jeszcze nie widać, ale można matematycznie ocenić jego prawdopodobieństwo. Sformalizowane relacje, zawiązane dzięki doskonale wyszkolonej podczas licznych kursów i warsztatów zręczności, mają być z założenia nietrwałe, bo dzisiejszy Odyseusz, ten self-made man, nie powinien się do niczego przywiązywać. Gdy powinie mu się noga, jego okręt nie zejdzie na dno, szybko się wynurzy, holować go bowiem będzie cała flota podobnych do niego wyższych jaźni, którym nie jest na rękę uszczuplenie i tak wąskiego grona ludzi sukcesu. Naukowa metoda dowiodła, że opłaca się być eleganckim i uśmiechniętym, określiła wszystkie kompetencje umożliwiające życie w świecie standardów burżuazyjnych wymalowanych arogancko na Olimpie i proklamowała je ustami całych społeczeństw pragnących puścić się w szalony wyścigu karier. Tym samym odczarowany świat oświecenia sam obrócił się na powrót w zaklęty mit norm transcendentalnych. Owa ideologia utrzymywana jest przez tę właśnie armię podmiotów, która obmyśliła, jak można dzięki przemyślnej zasadzie zachować swoje pozycje, i wyryła skłonność do takiego życia i takie ambicje delikatnymi, acz zmasowanymi stuknięciami w płytę ludzkiej wyobraźni. Na każdym kroku natykamy się na perswazję o przemożnej sile argumentów dotyczącą tego, co naprawdę warto. Efekt jest oszałamiająco oczekiwany, świat obraca się tak, jak założono. „Dialektyka: przewidzieć, że dom się spali, po czym rozlać benzynę koło pieca" ${ }^{38}$ - ujmuje w metaforze Miłosz. Adekwatna dzisiaj parafraza tej metafory brzmi „dialektyka: powiedzieć, że najwyższym dobrem jest rynkowy sukces, a następnie obliczonymi naukowo środkami wpoić to społeczeństwu do głów”.

Człowiek powołany do życia przez oświecenie samodzielnie ryzykuje i samodzielnie ponosi ofiarę. O warunki własnego przetrwania walczy w pojedynkę. Dlatego swojego zysku nie będzie z nikim dzielił, ewentualnie tylko z tymi, którzy byli lub będą mu bezpośrednio pomocni przy osiągnięciu celu. Do tego w istocie sprowadzają się inni otaczający go ludzie: są rywalami, choć bywają także użyteczni; można ich

38 C. Miłosz, Zniewolony umyst, s. 23. 
wtedy wliczyć w rachubę. Taka jest podstawowa zasada, na której opiera się nowoczesne społeczeństwo, przekonują Horkheimer i Adorno. Zasada ta jest wyznaczona przez burżuazję, choć obejmuje wszystkie klasy postoświeceniowego świata, który napędza. Jest nią stosunek ustawiający otoczenie podmiotu w roli narzędzi, które można wykorzystać na drodze do jego własnego zysku. Każda uformowana jaźn podporządkowuje sobie innych ludzi i zapanowując nad nimi, zaprzęga ich do osobistych interesów. Społeczeństwo oparte na takiej regule z konieczności wiąże się z władzą, która przenika każdą relację. Relacja panowania i podległości jest najważniejszą z tych, jakie łączą niezależne od siebie jaźnie, o podmiotach „niedojrzałych”, niezdolnych do samodzielnego przetrwania już nie wspominając. Bowiem „logicznym podmiotem oświecenia jest burżuazja w kolejnych swoich wersjach: właściciela niewolników, wolnego przedsiębiorcy, administratora"39.

Analogia między nowoczesnym człowiekiem a jego prawzorem Odyseuszem niesie ze sobą pewnego rodzaju materialistyczny fałsz, który zaciera się w horyzoncie ideologii. Dzięki jej wpływowi dzisiejsza podmiotowość jest mimo wszystko potomkiem homeryckiego bohatera $\mathrm{z}$ prawego łoża.

Owo fałszywe zrównanie Odyseusza $\mathrm{z}$ współczesnymi herosami kapitalizmu wynika z tego, że postęp cywilizacyjny pozwolił zdystansować się społeczeństwom wobec żywiołów natury. Jeżeli Odyseusz walczył o życie, ocierał się o granice przetrwania, granicę warunków własnej egzystencji, to dzisiejsze społeczeństwa opływają w dobrobyt. Dotyczy to oczywiście „globalnej północy”, państw liberalnej demokracji zdominowanych przez kapitalizm, które bez wątpienia swój rozwój ekonomiczny zawdzięczają $\mathrm{w}$ dużej mierze temu, że w pozostałych regionach świata utrzymują dyktatorskie lub autorytarne ustroje gwarantujące niewolniczą organizację pracy, a przez to minimalizację kosztów produkcji towarów produkowanych na eksport. To tam, w tych innych rejonach świata, każdego dnia odbywa się heroiczna walka o przetrwanie. To tamte społeczeństwa wystawione są na kapryśne żywioły natury i łaskę swych panów. Według różnych danych liczba pracujących dzisiaj niewolników waha się między 18 a $36 \mathrm{mln}$, i nie dotyczy to tak zwanego bonded labour, czyli niewolnictwa podyktowanego głodem, nędzą, uwikłaniem w długi i powinności rodzinne, klanowe, plemienne i kastowe. Szacunkowa skala takiego rodzaju niewolnictwa mieści się - szacowania są niepewne z powodów problemów metodologicznych - między $300 \mathrm{mln}$ a $3 \mathrm{mld}^{40}$. W 2009 roku majątki 1\% najbogatszych ludzi na świecie stanowiły 44\% całości „bogactwa narodów”, w 2016 roku ten sam $1 \%$ dysponował ponad połową całego majątku ludzkości ${ }^{41}$. Liczby te nie są przypadkowe: ich współzależność wynika z mechanizmu globalnego kapitalizmu.

\footnotetext{
39 M. Horheimer, T.W. Adorno, Dialektyka Oświecenia, s. 87.

40 http://ewangelicki.pl/erpublica/niewolnictwo-ma-sie-dobrze-tomasz-piatek/ (dostęp 5.06.2015).

41 P. Szumlewicz, By żyło się lepiej, w: idem: Bez Dogmatu, nr 1 (103), Warszawa 2015, s. 3.
} 
Wiedzieli to już w czwartej dekadzie XX wieku frankfurtczycy. „Wzrost wydajności ekonomicznej - pisali - który z jednej strony stwarza warunki dla sprawiedliwszego świata, z drugiej strony użycza aparaturze technicznej i grupom społecznym, które nią rozporządzają, bezmiernej przewagi nad resztą ludzi”"42.

W krajach rozwiniętych ludzie bez trudu pokonują poprzeczkę samozachowania dzięki zawrotnej produktywności i rozwojowi techniki. Nie zmienia to wszakże nic w panujących tam stosunkach społecznych. Ponieważ nie tylko samo życie, ale i więź społeczna ma swoją cenę, także mieszkańcy bogatych regionów codziennie walczą o swoje społeczne przetrwanie. Choć głodem przymierać raczej nie będą, mogą zostać wykluczeni z instytucji kształtujących zbiorowe bycie. Ale partycypować $\mathrm{w}$ tym życiu będą zawsze samotnie, ponieważ kapitalizm jest systemem, który z każdą jednostką chce rozprawić się osobno, każdego - przez swoje ideologie - do walki o przetrwanie wyzywa w pojedynkę. Podmioty zbiorowe są dlań niebezpieczeństwem i przeszkodą. W kapitalizmie zaiste ziszcza się maksyma divide et impera.

Strategia Odyseusza pozostaje nadal w mocy, jakby każdego dnia realnym zagrożeniem była groźba utraty życia. Dzieje się tak dlatego, że panuje zniekształcająca ten stan rzeczy ideologia, która sankcjonuje balansowanie na granicy samozachowania. Powoduje ona, że ludzie adaptują się do warunków gry wyzysku, przyjmując na siebie rolę i brzemię Odyseusza. Instynktownie boją się utraty warunków bezpiecznego bytu. Nawet gdy nie czerpią zysków z wartości dodatkowej, lecz są poddani wyzyskowi zdeterminowanemu przez abstrakcyjną akumulację - jeśli kapitalizm nie jest dla nich karmicielką, lecz wampirem - zamiast organizować opór, boją się, że stracą źródło przetrwania i śnią, że są Odyseuszami, którzy wkrótce staną się również prawdziwymi beneficjentami systemu. Ideologicznie wymuszona indywidualna praktyka jako mentalny reżim podtrzymujący niesprawiedliwe stosunki społeczne niezmiennie od XIX wieku usprawiedliwia nieludzki wyzysk.

42 M. Horheimer, T.W. Adorno, Dialektyka Oświecenia, s. 12. 


\title{
Ideologia jako powołanie płynące $\mathrm{z}$ centrum
}

\author{
Idź, bo tylko tak będziesz przyjęty do grona zimnych czaszek \\ do grona twoich przodków: Gilgamesza Hektora Rolanda \\ obrońców królestwa bez kresu i miasta popiołów
}

Bądź wierny Idź

Bąd́ wierny idźt

W punkcie, w którym mówimy o indywidualnej strategii Odyseusza i praktyce przetrwania, spotyka się myśl uosabianej przez Adorna i Horkheimera szkoły frankfurckiej ze strukturalistycznym marksizmem Louisa Althussera.

Jak się to dzieje, że mechanizm codziennego rytmu życia raz nakręcony, działa stale w identycznych powtarzalnych sekwencjach bez zarzutu? Przecież - przynajmniej w państwach liberalnej demokracji, na której (głównie) tutaj się skupiam nikt (raczej) nikogo do pracy nie prowadzi pod karabinem. Istota rzeczy leży gdzieś w motywacjach codziennych praktyk społecznych jednostek i prowadzi do stanowiącego temat mojego eseju pytania o formę podmiotu kapitalistycznego.

Można starać się odpowiedzieć na to pytanie, będąc ślepo przywiązanym do idei bezpośredniej determinacji nadbudowy przez bazę. Wówczas sprawcza rola własnej świadomości jednostki byłaby znikoma, a jedyna odpowiedź na pytanie, dlaczego każdego dnia przedsiębiorstwo zapełnia się stałą załogą, będzie taka, że pracownicy poddani bytowej konieczności pragną jedynie uzyskać płacę zapewniającą przeżycie im samym i ich rodzinom. Jeśli przyjąć taki pogląd, osoba, której płaca przestanie odpowiadać historycznie określonym potrzebom konsumpcyjnym, powinna - będąc racjonalnie kalkulującym podmiotem - znaleźć nowe miejsce zatrudnienia lub jeszcze lepiej: wywrzeć wraz z innymi postawionymi w podobnym położeniu nacisk na właścicielach kapitału. Lecz gdyby była to zasada uniwersalna, kapitalizm byłby dzisiaj w odwrocie, bo we wszystkich niemal fabrykach świata, w większości przedsiębiorstw płonęłyby strajkowe opony, wzniecony pracowniczy opór cieszyłby się szeroką społeczną akceptacją. Tak jednak się nie dzieje. Przeciwnie, zamiast organizować opór, pracownicy przykładnie zdążają do swoich miejsc pracy, jakby byli do niej wręcz powołani przez jakąś absolutną instancję. Akumulacja kapitalistyczna w natarciu święci triumfy.

Punktem wyjścia do badań nad tym fenomenem jest sporządzona przez Althussera rekonstrukcja marksowskiej topiki (przestrzennej metafory) bazy i nadbudowy

43 Z. Herbert, Pan Cogito, Wrocław 1997, s. 88. 
przedstawiająca piętrową budowlę, której najniższym poziomem jest baza odpowiadająca społecznej infrastrukturze, czyli materialnym stosunkom produkcji. Kolejne piętra obrazują to, co Marks zwie społeczną nadbudową, obejmującą prawo i państwo, oraz różne ideologie moralne, prawne i polityczne. Konstrukcja ta ukazuje, że istotnie, kierunek determinacji jest zwrócony ku górze: ostatnią instancją podtrzymującą wszystkie pozostałe poziomy jest społeczna baza. „Metafora przestrzenna uznaje bazę za wskaźnik skuteczności, znany pod sławnymi terminami: determinuje w ostatniej instancji to, co się dzieje na «piętrach» (nadbudowy) poprzez to, co dzieje się w bazie ekonomicznej”"44. Należy tu wszakże wyjaśnić, co w marksowskiej teorii oznacza pojawiająca się ,względna autonomia" nadbudowy i „zwrotne działanie” nadbudowy na bazę. Właśnie to zagadnienie podejmuje francuski filozof.

W rozsławionej już pracy Ideologiczne aparaty państwa Althusser stara się zgłębić przyczynę obserwowanego faktu, że każdy członek formacji społeczeństwa kapitalistycznego ,jutro - każdego jutra danego przez boga - stawia się u bram przedsiębiorstwa"45. Jest to pytanie dotyczące kwestii reprodukcji warunków produkcji.

Należy tu wyróżnić dwie osobne sprawy. Pierwsza to reprodukcja materialnych warunków produkcji: „każdego roku trzeba przewidzieć, czym zastąpić to, co się wyczerpuje lub zużywa w procesie produkcji: surowce, środki trwałe (budynki), narzędzia produkcji (maszyny), itd." ${ }^{\prime 6}$. Tę sprawę należy badać na poziomie globalnym, ponieważ każdy poszczególny zakład uzależniony jest od produkcji innego zakładu:

MX..., kapitalista, produkujący w swojej przędzalni wełniane tkaniny, musi „reprodukować" surowce, maszyny itp. Ale nie on je produkuje dla swojej produkcji, lecz inni kapitaliści: wielki australijski hodowca owiec MY, wielki producent maszyn MZ... itd., którzy - aby wytwarzać produkty warunkujące reprodukcję warunków produkcji MX - sami muszą produkować warunki własnej produkcji, i tak w nieskończonośćc ${ }^{47}$.

Drugi aspekt, czyli reprodukcja siły roboczej, jest bardziej złożony. Składa się nań „współczynnik materialny”, czyli narzucone przez walkę (przeciw obniżaniu płacy i zwiększaniu czasu pracy ${ }^{48}$ ) klasy proletariackiej historyczne minimum pracy. Ponadto siła robocza musi być kompetentna i zdolna do wypełniania zadań przypisanych poszczególnym grupom w ramach społecznego podziału pracy, innymi słowy, musi reprodukować się jako siła robocza właśnie, a nie tylko biologiczne i empi-

\footnotetext{
44 L. Althusser, Ideologie i aparaty ideologiczne państwa, Warszawa 2006, s. 6.

45 Ibidem, s. 4.

46 Ibidem, s. 3.

47 Ibidem.

48 Ibidem.
} 
ryczne jednostki. Toteż siła robocza powinna być zawczasu, jeszcze przed wykorzystaniem jej w procesie produkcyjnym, wyszkolona i wykwalifikowana. Winna ona charakteryzować się określonym typem osobowości. Ten właśnie typ osobowości w moim opracowaniu poddaję analizie. We współczesnej formacji społecznej „reprodukcja kwalifikowanej siły roboczej $[\ldots]$ nie zachodzi już «w ogniu pracy», lecz w coraz większym stopniu poza produkcją: przez kapitalistyczny system szkolnictwa oraz inne instancje i instytucje" ${ }^{\text {". }}$. Przeto już u samego początku kapitalistyczna edukacja konserwuje klasowy charakter społeczeństwa i uczy reguł społeczno-technicznego podziału ustanowionego przez podziały klasowe. Wpaja w ten sposób techniki i umiejętności, które następnie będą użyteczne na poszczególnych szczeblach produkcji. „Jeden rodzaj wykształcenia dla robotników, drugi dla techników, trzeci dla inżynierów, ostatni wreszcie dla kadr wyższych. Przyszłych kapitalistów uczy się, jak dobrze komenderować $\mathrm{i}$ «dobrze mówić» do robotników" ${ }^{50}$. Althusser stara się tym samym pokazać, jak reprodukcja warunków produkcji wymaga nie tylko wyrobienia odpowiednich kwalifikacji, ale także reprodukcji podporządkowania ideologii robotników i posługiwania się nią przez przedstawicieli burżuazji.

To rozpoznanie niezwykle dobrze koresponduje z rolą wiedzy w „oświeceniowych” społeczeństwach, jaką opisywali Adorno z Horkheimerem. Kapitalistyczny system szkolnictwa jest pewnym przypadkiem praktycznego zastosowania naukowej kalkulacji, zgodnie z którą upowszechnienie wiedzy ma służyć nie jej samej, lecz celom pragmatycznym. „Nie chodzi bowiem o owo spełnienie, jakie człowiekowi daje prawda, ale o operatio, o skuteczną metodę; «prawdziwym celem i funkcją nauki» są [...] «działanie, praca i odkrywanie nieznanych przedtem szczegółów, po to, by zyskać lepsze wyposażenie i pomoc w życiu»" ${ }^{51}$.

Szkoła obok kościołów, rodziny, prawa, kultury, mediów informacyjnych, struktur politycznych należy do tego, co Althusser określa jako ideologiczne aparaty państwa, w odróżnieniu od represyjnych aparatów państwa. Te ostatnie, takie jak rząd, policja, sądy, więzienia, wojsko, są publiczne, a ich cechą jest to, że działają na fundamencie przemocy. Ideologiczne aparaty państwa, choć różnorodne i przypisane do sfery prywatnej, zawsze są zunifikowane i działają w interesie klasy panującej. Oczywiście, słuszna jest nasuwająca się tutaj wątpliwość: „Wszystkie Aparaty Państwowe funkcjonują w oparciu jednocześnie o represję i o ideologię, z tą tylko różnicą, że (represyjny) Aparat Państwowy funkcjonuje przeważnie w oparciu o represje, natomiast Ideologiczne Aparaty Państwowe w oparciu o ideologię" 52 . Na przykład prawo podporządkowuje obywateli w sposób ideologiczny, ale na swój użytek sięga rów-

\footnotetext{
49 Ibidem, s. 5.

50 Ibidem.

51 M. Horheimer, T.W. Adorno, Dialektyka Oświecenia, s. 17.

52 L. Althusser, Ideologie i aparaty..., s. 12.
} 
nież niekiedy po instrumentarium fizycznej siły i ,poprzez represje (od najbardziej brutalnej siły fizycznej po zwykłe nakazy i zakazy administracyjne, jawną i ukrytą cenzurę itp.) zapewnia polityczne warunki działania Ideologicznych Aparatów Państwowych"s3.

Althusser, wbrew powszechnemu przekonaniu, stawia tezę, że po rewolucji burżuazyjnej rolę dominującego aparatu ideologicznego, którą wcześniej pełnił Kościół, przejęła właśnie szkoła, a nie aparat polityczny.

Na czym polega ideologiczność aparatu i wpisana weń ideologia? Francuski marksista stara się przekroczyć tradycyjną marksowską teorię ideologii, znaną między innymi z Ideologii niemieckiej, gdzie jej rozumienie odpowiada rozumieniu snu przed odkryciami Freuda. Tak jak sen był „resztką dnia” przypadkową, chaotyczną i zniekształconą, podobnie ideologia była dla Marksa po prostu zdeformowanym i urojonym przedstawianiem sobie własnych warunków bytowych. Z czego wynikać miałoby owo zdeformowanie? Przedmarksowskie oświecenie mówiło, że stoją za nim „proboszczowie i despoci”, którzy sączyli prostemu ludowi „piękne kłamstwa”, by uczynić go posłusznym. Marks i Ludwig Feuerbach zaproponowali inną odpowiedź. Twierdzą oni zgodnie, że ideologia wynika z materialnej alienacji, z tego, że człowiek w warunkach produkcji jest obcy samemu sobie i innym ludziom. $Z$ nich to wynika wyalienowane człowieka, a przez to urojone przedstawienie sobie warunków swego rzeczywistego istnienia. Idzie za tym pewna myśl dotycząca ahistorycznego charakteru ideologii. Historia ideologii jest poza nią, w jedynej realności materialnych stosunków produkcji. Oznacza to, że ideologia jest zawsze przypadkowo i dowolnie „skleconym” przedstawieniem jedynej pozytywnej realności, czyli „realności konkretnej historii konkretnych, materialnych jednostek wytwarzających materialnie swoją egzystencję" ${ }^{54}$.

Z podobnym pojęciem ideologii Althusser chce zerwać i zamiast przyjąć, że nie ma ona historii w znaczeniu pozytywistyczno-historycznym (jak uważał Marks, mówiąc, że historia jest poza nią), powiada, że nie ma ona historii dlatego, że jest ponadhistoryczna. Należy to rozumieć w ten sposób, że podobnie jak sen u Freuda, ideologię należy badać jako pewną niezmienną w czasie symboliczną strukturę znaczeń.

Kolejnym elementem odróżniającym myśl francuskiego filozofa od innych pokrewnych mu myślicieli jest zerwanie przezeń z rozumieniem ideologii jako pewnej koncepcji świata, którą bada się podobnie do mitów społeczeństw pierwotnych, przez odkrywanie w nich elementów urojonych i aluzyjnych wobec rzeczywistości. Ideologia dla Althussera nie jest samym odbiciem i transpozycją realnych warunków egzystencji w jakimś transcendentalnym horyzoncie. Korekta Altussera polega więc na tym, że ideologia jest przedstawieniem urojonego stosunku jednostek do tych re-

\footnotetext{
53 Ibidem, s. 13.

54 Ibidem, s. 17.
} 
alnych warunków bytowych. Przyczyną deformacji jest więc nie alienacja czy kłamstwo i cynizm kapłanów, lecz sam ten stosunek i jego urojeniowy charakter.

Dalej, by zrekonstruować tę teorię, należy powiedzieć, że ideologia zawsze istnieje w aparacie ideologicznym: jego praktyce i praktykach, istnieje przeto materialnie. Nie chodzi tu o podmiot, który w swoim wnętrzu rozważa i wierzy wyrażone w ideologii idee, ale o podmiot, który uczestniczy i działa zgodnie z założonymi przez te idee praktykami. Termin idee, który odsyła do subiektywnych przekonań, możemy na tym etapie zastąpić takimi pojęciami, jak praktyki, rytuat, aparat ideologiczny. Podmiot działa więc o tyle, o ile jest wprawiany w ruch przez system: „ideologia istniejąca $\mathrm{w}$ materialnym aparacie ideologicznym narzuca materialne praktyki regulowane przez materialne rytuały, które to praktyki istnieją w materialnych aktach podmiotu działającego z całą świadomością według swego przekonania" ${ }^{55}$.

Wywód ten podsumowują dwie tezy: jedna, że praktyka istnieje tylko dzięki i w ideologii, i druga, że istnieje ona tylko dzięki podmiotom i dla podmiotów.

Pisałem wcześniej, że brak oporu klasowego przeciw wyzyskowi i posłuszne stawianie się robotników codziennie w fabryce przywodzi na myśl przypuszczenie o powołaniu ich przez jakąś nadrzędną instancję. Tym powołaniem jest ideologiczna interpelacja jednostek jako podmiotów. Kategoria podmiotu musi występować jako największa oczywistość, bo samą istotą ideologii jest to, że narzuca oczywistości. Althusser, żeby zilustrować działanie tej oczywistości, przywołuje przykład, gdy pukający do drzwi przyjaciel na moje pytanie: „kto tam?” odpowiada: „to ja”. Drzwi zostają otworzone, a po drugiej stronie progu istotnie stoi ów przyjaciel, którego spodziewałem się ujrzeć. Założona oczywistość zostaje w ten sposób potwierdzona.

Drugą ilustracją jest uliczna sytuacja, kiedy na wezwanie policjanta: „Hej, ty tam” jednostka, o którą chodziło, odwraca się. Całe zajście odbywa się bezbłędnie: za każdym razem odwraca się ten właśnie osobnik, który został wezwany. I choć pozornie nic się nie zmienia, potwierdza się w nim odwieczna zasada ideologii. Pamiętamy przecież, że Althusser szuka jej ponadhistorycznej struktury: ,ideologia zawsze i wciąż interpeluje jednostki, aby stały się podmiotami, co wymaga uściślenia, że jednostki zawsze były interpelowane przez ideologię do zostania podmiotami, co z koniecznością prowadzi nas do ostatniej propozycji: jednostki zawsze już są podmiotami" ${ }^{56}$.

Niezmiernie ważną obserwacją jest, że to, co dzieje się poza ideologią, w rzeczywistości dzieje się w niej. Ideologia bowiem nigdy nie przyzna się sama do siebie.

W rozważaniach Althussera następuje w tym miejscu kolejny przykład, który ma posłużyć do dalszych badań nad uniwersalną strukturą ideologii. Tym przykładem jest ideologia religijna. Zgodnie z założeniem sposób, w jaki zwraca się do jednostek,

55 Ibidem, s. 21.

56 Ibidem, s. 24. 
by je interpelować jako podmioty, nie sprowadza się tylko do mowy pism i kazań; działa ona przez praktyki i rytuały, ceremonie i sakramenty. Religia chrześcijańska zwraca się do każdej jednostki, by przekształcić ją w podmiot i nadać tożsamość osobową:

oto, kim jesteś - jesteś Piotrem! [...] zostałeś stworzony przez Boga na całą wieczność, jakkolwiek urodziłeś się w 1920 roku po Chrystusie! Takie jest właśnie twoje miejsce w świecie! To właśnie powinieneś robić! Dzięki temu, przestrzegając „prawa miłości”, będziesz zbawiony, ty Piotrze, i staniesz się częścią Ciała chwały Chrystusa! ${ }^{57}$

Jeżeli ta procedura interpelacji obecna w praktykach i ceremoniach chrztu, komunii czy spowiedzi skutecznie oddziałuje na jednostki, które rozpoznają w tej konstrukcji własne miejsce, oznacza to według Althussera, że warunkiem istnienia tak licznych podmiotów jest istnienie jakiegoś centralnie usytuowanego Absolutnego Innego Podmiotu, który w tym przypadku jest Bogiem. Interpeluje on - jak Mojżesza w Starym Testamencie - swoich interlokutorów, stworzonych na jego obraz i podobieństwo, by byli jego lustrzanym odbiciem. „Bóg potrzebuje ludzi, podmiot potrzebuje podmiotów, tak samo jak ludzie potrzebują Boga, podmioty potrzebują Podmiotu. Lepiej: Bóg potrzebuje ludzi, wielki Podmiot potrzebuje podmiotów, aż do potwornego odwrócenia w nich swego obrazu" 58 .

Dalej, ponieważ Bóg posyła swojego Syna, będącego zarazem zwykłym podmiotem i Wielkim Podmiotem, następuje redublowanie Wielkiego Podmiotu na podmioty i samego Wielkiego Podmiotu na podmiot - Wielki Podmiot, które wymaga wyjaśnienia i interpretacji. Otóż - powiada Althusser - struktura każdej interpelacji jest ześrodkowaną strukturą odzwierciedlającą. Wielki Podmiot:

interpeluje wokół siebie niezliczone jednostki [...] dając im - w Podmiocie, gdzie każdy podmiot może kontemplować swój własny wizerunek (obecny i przyszły) gwarancje, że jest to dobre dla nich i dobre dla Niego, [...] i że [...] „Bóg rozpozna swoich", to znaczy tych, którzy rozpoznają Boga i będą w nim rozpoznani, i ci właśnie będą zbawieni ${ }^{59}$.

Cały ten mechanizm, jak widać, powoduje, że podmioty „maszerują całkiem same" ${ }^{60} \mathrm{w}$ ramach praktyk założonych przez ideologie $\mathrm{w}$ Ideologicznych aparatach państwa podległe Wielkiemu Podmiotowi w konkretnych jego figurach: dyktatora,

\footnotetext{
57 Ibidem, s. 25.

58 Ibidem, s. 26.

59 Ibidem.

60 Ibidem, s. 27.
} 
Boga, właściciela lub menedżera fabryki albo korporacji. Odsłonięta zostaje tu także językowa dwuznaczność podmiotu, który jest zarazem subiektywnością, wewnętrznym centrum inicjatywnym, jak i subiektem, czyli poddanym, bytem ujarzmionym, podporządkowanym ,wyższemu autorytetowi, a zatem pozbawiony wolności, z wyjątkiem wolnego zaakceptowania swej podległości”"61.

Podsumowując teorię Althussera, przypomnijmy sobie w tym miejscu, że warunkiem oświecenia było powstanie nowoczesnego podmiotu, jaźni, która miała podjąć wyzwanie walki o przeżycie. Czyż Odyseusz nie jest właśnie jednostką interpelowaną przez Innego? Czyż dzisiejsi Odyseuszowie nie są w ten sam sposób interpelowani do samodzielnego wspinania się po szczeblach kariery? Człowiek w okresie swojej dojrzałości, który miał być - jak chciał tego Immanuel Kant - podmiotem oświecenia uwolnionym spod władzy autorytetu, popadł znów w niewolę i usidlony został przez kapitalistyczną ideologię, także zmaterializowaną i przejawiającą się w konkretnych praktykach walki o staż, inwestowania w siebie dla wzmocnienia rynkowej pozycji, gry o awans.

W latach, gdy Althusser pisał Ideologiczne aparaty państwa, w szczątkowej formie występowała jeszcze alternatywna kultura i dumna tożsamość robotnicza. To przed nią i przed jej klasową walką ideologiczne aparaty państwowe musiały się bronić, chcąc zachować dominującą pozycję. W Post Scriptum do swojego tekstu francuski marksista pisze:

W istocie Państwo i jego Aparaty posiadają znaczenie tylko z punktu widzenia walki klasowej, jako aparat walki klas, zapewniający ucisk klasowy i zabezpieczających warunki wyzysku i reprodukcji. Ale walka klas bez klas antagonistycznych nie istnieje. Kto mówi o walce klasowej klasy panującej, mówi jednocześnie o oporze, rewolucji i walce klasowej klasy podporządkowanej ${ }^{62}$.

Miał szczęście, że dane mu było widzieć jeszcze ten klasowy opór, prawie nieznany naszym czasom. Jakoż dzisiaj dopiero Wielki Inny interpeluje każdego ze zdwojoną siłą: „Ty jesteś samodzielnym Odyseuszem na oceanie globalnej gospodarki! Inwestuj w siebie, pnij się, by na szczycie akumulacji kapitału pić ze mną kielich przymierza i czerpać wszelkie korzyści, jakie daje władza i bogactwo, gdy inni będą pracować za ciebie. Oto składam ci obietnicę: jako menedżer, biznesmen, właściciel kapitału sam staniesz się dla nich Wielkim Innym! To wszystko będzie dobre. Dla mnie i dla ciebie!".

Nastał czas, gdy wszelkie alternatywne tożsamości czy nawet ideologicznie interpelowane podmiotowości zastąpione zostały uniwersalną osobowością burżuazyjno-

\footnotetext{
61 Ibidem.

62 Ibidem, s. 28.
} 
-biznesową. Podmiotowością, dzięki której wszyscy „maszerują sami”, w każdym miejscu na świecie niezawodnie reprodukując warunki produkcji. Ale ponieważ cały ten kręcący się moloch oparty jest tylko na urojonym przedstawieniu stosunku jednostek do ich warunków bytowych, brakuje mu umocowania w realnym bycie. Konstrukcja molocha bazuje więc tylko na zasadzie dośrodkowej siły interpelującej skupione wokół Innego jednostki, nie zaś na materialnej konieczności, jakiej poddany był na przykład Odyseusz, walcząc o własne przeżycie. Ta bowiem zakłada antagonizm i stawiającą opór rzeczywistość.

W pewnym miejscu Althusser porównuje rolę praktyk ideologicznych do pascalowskiej praktyki wiary: wierzysz czy nie - zachowuj się jakbyś wierzył: padnij na kolana i poruszaj wargami. Prymarną kwestią w tym przykładzie, a także w Ideologicznych aparatach państwa - co starałem się pokazać - jest sama praktyka, nie wiara i idee, które są w głowie. Dlatego zasadne wydaje się pytanie, czy ktokolwiek w kapitalistyczną praktykę naprawdę wierzy. A może nikt w nią nie wierzy, ale wszyscy ,tak robią”, bo..., „robią tak” wszyscy?

\section{Wierzymy interpasywnie, czyli wiara, że wierzy Inny}

dlatego tė jesteśmy w swych poczynaniach zarazem bardziej niezależni i bardziej pasywni niż ludzie minionych epok. Konformizm stat się obecnie norma ${ }^{63}$.

Wyjaśnienia opisanego powyżej stanu rzeczy dostarcza nam strukturalna psychoanaliza Jacquesa Lacana. Już zresztą Althusser w przytaczanych fragmentach wskazywał na pokrewieństwo i analogię między odkryciem Freuda a własnym sposobem badania ideologii. Z całą pewnością można powiedzieć, że lingwistyczna aktualizacja nauki niemieckiego terapeuty, jakiej dokonał Lacan, pozwala jeszcze lepiej łączyć obu tych francuskich myślicieli. Jako homologiczne i paralelne cechy ich teorii można podać język, który w przypadku psychoanalizy strukturyzuje nieświadomość, zaś w przypadku marksistowskiej analizy - ideologię.

Wprawdzie początkowo przedmiot badań i rozpoznania autora znanych Seminariów dotyczyły intersubiektywnych relacji (nawiązując do heglowskiej dialektyki uznania) natury fenomenologicznej, z czasem jednak ewoluowały one w stronę analizy anonimowych mechanizmów strukturalnych regulujących działania i interakcje podmiotów. Aby zrozumieć, jakich wskazówek i odpowiedzi dotyczących proble-

63 P. Sloterdijk, Krytyka cynicznego rozumu, s. 18. 
mu ideologii udziela nam Lacan, postaram się najpierw zarysować zrąb jego teorii. Jednak przeskoki między częściami moich rozważań: sprawozdawczą i problemową, w której zastosuję psychoanalityczne narzędzia do moich własnych prób opisania osobowości kapitalistycznej, będą nieledwie widoczne. Na marginesie dodam, że korzystać będę ze specyficznie autorskiej lektury Lacana słoweńskiego filozofa Slavoja Žižka.

Teoria rzeczywistości ludzkiej Lacana zakłada trzy oddziałujące na siebie wzajemnie porządki: symboliczny, wyobrażeniowy i realny ${ }^{64}$. Interakcje między społecznymi aktorami są regulowane w ostatecznej instancji przez porządek symboliczny. Jest on „niepisaną konstytucją społeczeństwa" ${ }^{65}$. To dzięki niemu potrafimy się ze sobą komunikować $\mathrm{i}$ to on podsuwa nam gotowy do użycia język wraz z jego zasadami: tymi, których jesteśmy świadomi, i tymi, które znamy, nie wiedząc o tym. „Kiedy mówimy (albo słuchamy), nigdy nie jest tak, że wchodzimy w interakcje tylko z innymi ludźmi; nasza czynność mówienia jest ugruntowana w tym, że akceptujemy złożoną sieć reguł oraz innego rodzaju założeń"

Na poziomie symbolicznym pierwszoplanową rolę gra Wielki Inny (intuicja nieodparcie i jak najbardziej słusznie odsyła nas w tym miejscu do Wielkiego Podmiotu u Althussera), który zapośrednicza każdą interakcję między jednostkami. Służy on jako punkt odniesienia, do którego się porównujemy, i może występować pod postacią Boga albo jakiejś „,wielkiej sprawy” nadającej sens naszemu życiu. Działa on jak metaforyczne lustro, w którym możemy się przeglądać z nadzieją, że jesteśmy przez Innego widziani. Dla moich rozważań istotny jest fakt, że Wielkiemu Innemu brakuje substancji, że działa on tylko dlatego, że podmioty same działają tak, jak gdyby on istniał. Realność jego istnieniu i siłę jego działaniu w rzeczywistości społecznej nadaje tylko to, że ,jest wierzony”. Po raz kolejny możemy tutaj zauważyć adekwatność pascalowskiej maksymy: „upadnij, módl się, jakbyś wierzył, a wiara przyjdzie sama".

Wielki Inny ma także inną ważną dla moich rozważań funkcję: potrafi przeżywać w naszym imieniu. To zjawisko, nazwane przez Lacana interpasywnością, można zrozumieć na przykładzie ukrytego śmiechu zza sceny obecnego w różnego rodzaju komediowych serialach telewizyjnych. Oglądając podobny program, nie musimy śmiać się sami, gdy bohaterowie zrobią lub powiedzą coś śmiesznego, bowiem śmiech odpowiadający na tę sytuację został uwzględniony w warstwie dźwiękowej komedii, a my oddając się innym czynnościom, możemy czuć się w pełni odprężeni. Podobnie działa dzisiaj ideologia. Nie musimy w nią wierzyć, ważne, że ona wierzy za nas, my zaś dzięki temu będziemy codziennie oddawać się ideologicznym praktykom.

64 S. Žižek, Lacan. Przewodnik Krytyki Politycznej, Warszawa 2010, s. 24.

65 Ibidem.

66 Ibidem, s. 25. 
Mamy tu do czynienia z psychoanalitycznym przeniesieniem wiary na kogoś innego, na „podmiot założonej wiary”: „aby wiara działała, podmiot, który wierzy, wcale nie musi istnieć, naprawdę: wystarczy tylko, że założymy jego istnienie, uwierzymy $\mathrm{w}$ to, że istnieje albo pod postacią mitologicznej figury założyciela, albo pod postacią bezosobowego i niekreślonego podmiotu - «Mówią, że...», «Mówi się, że...»"67 pisze Žižek, przekonując zarazem, że dzisiaj rola praktyk może służyć także pozbyciu się wiary: „działaj jakbyś wierzył, a pozbędziesz się swojej wiary”68.

Można tłumaczyć to także na przykładzie marksowskiego fetyszyzmu towarowego. Marks twierdził, że przypisujemy towarom metafizyczną siłę, traktując je jak przedmioty o nadnaturalnych własnościach, podczas, gdy są one jedynie produktem zwyczajnych procesów produkcji zachodzących między ludźmi. Dzisiaj można chyba przyjąć, że wszyscy wiemy o tej zbiorowej iluzji, lecz - jak stwierdza Žižek - problemem jest to, czy ta iluzja wie o sobie samej, że nie jest niczym więcej.

Czy najbardziej podstawową cechą marksowskiego pojęcia fetyszyzmu towarowego nie jest to, że „rzeczy wierzą zamiast nas”? Warto bowiem bezustannie powtarzać, że w marksowskim pojęciu fetyszyzmu inwersja fetyszystyczna dokonuje się nie w tym, co ludzie myślą, że robią, lecz w samej ich działalności społecznej: typowy podmiot burżuazyjny jest we własnej świadomości utylitarnym nominalistą - w swej działalności społecznej, w wymianie na rynku, postępuje tak, jak gdyby towary nie były zwykłymi przedmiotami, lecz przedmiotami wyposażonymi w szczególne moce, jak gdyby były pełne „teologicznych kaprysów”. Innymi słowy, ludzie są całkowicie świadomi, jak się rzeczy mają, doskonale wiedzą, że towar-pieniądz jest jedynie urzeczowioną formą przejawiania się stosunków społecznych [...]; paradoks polega na tym, że w swej społecznej działalności postępują tak, jak gdyby, tego nie wiedzieli i byli posłuszni fetyszystycznemu złudzeniu $^{69}$.

Praktyki, które strukturyzują nasze życie, poddają je we władanie umacniającej strukturę wyzysku ideologicznej realności. Dlaczego się im jednak oddajemy, skoro brakuje nam wiary w nie? Żeby to zrozumieć, Žižek opisuje wszystkim znaną sytuację, kiedy grupa bliskich sobie osób wie o jakiejś nieprzyzwoitej drobnostce i każdy członek tej grupy wie również, że wiedzą o niej inni. Przyznanie się jednak do niej wywołałoby powszechne zażenowanie. Czy nie tak rzecz ma się z ujawnieniem absurdalnej i okrutnej natury kapitalizmu: publiczne powiedzenie tego zostałoby poczytane za „opiniotwórcze faux pas”? Rzeczywistość kapitalistycznego wyzysku jest jak król Andersena naga, lecz nikt nie odważy się tego głośno powiedzieć. Zamiast

\footnotetext{
67 Ibidem, s. 49.

68 Ibidem, s. 50.

69 S. Žižek, Przekleństwo Fantazji, Wrocław 2001, s. 163.
} 
tego gorączkowo oddajemy się praktykom, które będąc określone przez ideologię, tylko umacniają taką rzeczywistość. Žižek zauważa, że oddawanie się podobnej „pseudoaktywności” ma na celu niedopuszczenie, by coś wydarzyło się naprawdę:

Nawet w dzisiejszej polityce większym zagrożeniem jest nie tyle pasywność, ile właśnie pseudoaktywność, wola bycia aktywnym i partycypacji. Ludzie przez cały czas interweniują, starają się „,coś zrobić”, a nauczyciele akademiccy biorą udział w bezsensownych debatach. Tymczasem o wiele trudniej jest się wycofać i w tym nie uczestniczyć. Będący u władzy często nawet wolą krytyczną partycypację od ciszy - byle tylko włączyć nas do dialogu i upewnić się, że nasza złowieszcza pasywność została złamana ${ }^{70}$.

Przypomina to maksymę z Geparda Giuseppe T. di Lampedusy: czasami trzeba zmienić wszystko, by nic nie uległo zmianie. Pseudoaktywność i wola ciągłej zmiany, która nie wykracza poza wyznaczone ramy i reguły gry, tylko tę grę umacnia. Być może ruchem, którego dzisiaj nam trzeba, jest odmowa wykonywania posunięć na szachownicy i próba wyskoczenia poza nią.

Podobnie do Žižka, który pisze o charakterystycznej dla współczesności postawie cynicznej obojętnej na to, że ideologia bezczelnie wykłada swoje karty na stół, ujawniając sekret swojego działania ${ }^{71}$, ów problem powszechnej świadomości istnienia ideologii rozpoznaje w swojej Krytyce cynicznego rozumu niemiecki filozof Peter Sloterdijk. Pisze on, że odeszły w niepamięć czasy, gdy logika oświecenia miała obnażać i obalać fałszywą świadomość, skłaniając uświadomione już jednostki do słusznego postępowania. Twierdzi, że klasyczna krytyka ideologii skończyła się, bowiem dzisiaj wszyscy są jej świadomi. Krytyka ideologii - powiada Sloterdijk - „stała się bardziej naiwna niż świadomość, którą pragnęła zdemaskować; ze swą układną racjonalnością nie nadążała za przemianami nowoczesnego myślenia, które wiodły ku wielu odmianom nowoczesnego myślenia, które wiodły ku wielu odmianom wyrafinowanego realizmu" 72 .

Inaczej niż Horkheimer czy Adorno, polemizujący z oświeceniem, które pozbawione rozumu celowego, w bezrefleksyjnej apoteozie rozumu instrumentalnego doprowadza w swej konsekwencji do fabrykacji śmierci - Holokaustu, Sloterdijk twierdzi, że refleksyjności bynajmniej nam nie brakuje. Mamy jej aż w nadmiarze, a do wzajemnego rozszyfrowywania ideologii dochodzi na każdym kroku. „Cynicy nie są bowiem głupcami i na wskroś przejrzeli nicość, do której wszystko zmierza. Ich aparat jest wystarczająco elastyczny, by wmontować weń jako czynnik przeżycia

70 S. Žižek, Lacan ..., s. 45.

71 Ibidem, s. 154.

72 P. Sloterdijk, Krytyka cynicznego rozumu, Wrocław 2008, s. 19. 


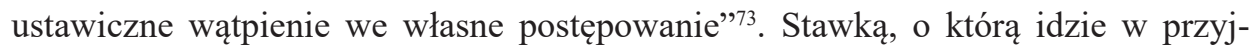
mowaniu postawy cynicznej, jest zdolność efektywnego wykonywania pracy mimo przenikliwej świadomości bezsensu działającego systemu. Niemiecki filozof nazywa to „świadomością kolaborującą”. Każdy, kto ma coś do stracenia, świadomie chowa się z tym, co wie, w prywatnym zaciszu, bądź świadomie swoją wiedzę thumi dodatkową konsumpcją i rozrywką oferowaną przez przemysł kulturalny.

Produkcja kulturalna na masową skalę, która z jednej strony jest tworzona, by zaspokoić potrzeby ludzi, z drugiej zaś podporządkowuje te potrzeby jednemu systemowi, poddaje je ogólności i kształtuje na swoją miarę. Wprowadza jednolite kryteria. Pozorna różnorodność przemysłu nie wynika z rzeczy samej, a tylko służy klasyfikacji konsumentów. „Budżetowe wyróżniki przemysłu kulturalnego nie mają zgoła nic wspólnego z merytorycznymi, z sensem produktu"74. Kant od podmiotu wymaga posługiwania jeszcze autonomicznych kryteriów intelektu, we współczesnym świecie kryteria te dyktuje przemysł. Obejmowanie kreowanej rzeczywistości jednym schematem jest pierwszym zadaniem przemysłu wobec konsumentów.

Jeżeli planowanie mechanizmu przez tych, którzy dostarczają danych, czyli przez przemysł kulturalny, narzucane jest temuż przemysłowi siłą bezwładu społeczeństwa, irracjonalnego mimo całej racjonalizacji, to jednak gdy owa fatalna tendencja przechodzi przez agentury interesu, zmienia się w przebiegły zamysł samego interesu $^{75}$.

Logiką działania przemysłu jest przemożna sugestia. Reklama, jak wiemy, nie tylko informuje o możliwości, ale przemyca sugestię o konieczności, mianowicie, że jej treść jest bezwzględną prawdą, a reklamowany przedmiot niezbędny do osiągnięcia zadowolenia. Skutecznym narzędziem przemysłu kulturalnego jest rozrywka. Dzięki niej przemysł dysponuje konsumentami: „przez immanentnie zawartą w zasadzie rozrywki wrogość w stosunku do wszystkiego, co jest czymś więcej niż rozrywką"76. Sama rozrywka

to przedłużenie pracy w późnym kapitalizmie. Poszukuje jej ten, kto chce się wymknąc zmechanizowanemu procesowi pracy, aby na nowo móc mu sprostać. Zarazem jednak mechanizacja ma taką władzę nad człowiekiem korzystającym z wolnego czasu i jego szczęściem, że określa dogłębnie wytwarzanie artykułów

\footnotetext{
73 Ibidem, s. 21.

74 M. Horheimer, T.W. Adorno, Dialektyka Oświecenia, s. 126.

75 Ibidem, s. 127.

76 Ibidem, s. 138.
} 
rozrywkowych, że człowiek ten może zetknąć się jedynie z wtórnymi obrazami samego procesu pracy ${ }^{77}$.

Im większa siła masowej kultury, tym mocniej odciska swoje piętno na potrzebach konsumentów i tym bardziej zbiorczo może te potrzeby traktować, obejmować coraz ściślejszymi ramami i kierować nimi. Rozrywka służy interesom przemysłu, ponieważ dobra zabawa jest zgodą na zastaną rzeczywistość. „Rozrywka jest możliwa, tylko gdy oddziela się szczelnie od całości społecznego procesu, ogłupia [...] dobrze się bawić znaczy zawsze: nie musieć o tym myśleć, zapomnieć o cierpieniu, nawet jeżeli jest pokazywane"78. Dobra zabawa jest zatem ucieczką nie tyle od złej rzeczywistości, ale od oporu, który jest jeszcze możliwy. Rozrywka, służąc panowaniu produkcji, serwuje łatwą i przyjemną papkę, zwalnia z myślenia i wyucza posłuszeństwa.

Można powiedzieć więc, że myślenie cyniczne, uchylając się od myślenia w kategoriach rzeczywistego oporu, oddaje się ochoczo ogłupiającej kulturze, a „swą wiedzę, niezdolną już do kąśliwych ataków, chowa głęboko do wnętrza niczym jakąś skazę"

By zilustrować ten mechanizm historycznym przykładem, najlepiej przywołać literacką analizę Miłosza, który w Zniewolonym umyśle opisuje rodzaj paktu, jaki w stalinizmie władza zawarła z elitą intelektualną, literatami i szeroko pojętą warstwą kulturotwórczą. Miłosz przytacza w swej książce opis zjazdów przedstawicieli ludzi kultury, w których sam uczestniczył. Podczas takich konwentów omawiano i proklamowano teorię socjalistycznego realizmu. Choć nastawienie słuchaczy do wygłaszających referaty prelegentów nie było przychylne, nie wywoływało to gremialnego sprzeciwu.

Wszyscy uważali socjalistyczny realizm za urzędowo narzucaną teorię, prowadzącą do opłakanych wyników, jak dowodził tego przykład sztuki rosyjskiej. Próby wywołania dyskusji nie udawały się. Sala milczała. Zwykle znajdował się jeden odważny, który przypuszczał atak pełen hamowanego sarkazmu, przy milczącym, ale wyraźnym poparciu całej sali. Odpowiedź referentów miażdżyła atakującego znacznie lepiej przeprowadzoną argumentacją ${ }^{80}$.

W dyskusji o dialektyce, która najpewniej sprowadziłaby się do Georga W.F. Hegla, nikt nie byłby w stanie dotrzymać pola dobrze przygotowanym prelegentom po-

\footnotetext{
77 Ibidem, s. 139.

78 Ibidem, s. 140.

79 P. Sloterdijk, Krytyka cynicznego rozumu, Wrocław 2008, s. 24.

80 C. Miłosz, Zniewolony umyst, s. 22.
} 
pierającym swoim savoir pouvoir wielkiego dyktatora, który sam cieszył się estymą najznamienitszego z mędrców i teoretyków. Nie znaczy to wszakże, że obecni słuchacze czuli się przekonani. Tę schizofrenię widział Miłosz, pisząc o Ketmanie - występującym w kulturze muzułmańskiego wschodu zjawisku podporządkowania się dominującym formom kulturowym, religijnym czy naukowym: „posiadacz prawdy nie powinien wystawiać swojej osoby, swego majątku i swego poważania na zaślepienie, szaleństwo, złośliwość tych, których Bogu spodobało się wprowadzić w błąd i utrzymywać w błędzie". Należy więc milczeć o swoich przekonaniach, jeżeli to możliwe ${ }^{81}$. Jednostka miała przed sobą wybór: oszukiwać, albo zginąc ${ }^{82}$. Ta sama alternatywa legła u podstaw społeczeństw postoświeceniowych. Obraz takiego świata napawa przygnębieniem tym bardziej, że siły w nim panujące zdają się mieć status metafizycznie niepodważalnych, takich, których nie sposób zwyciężyć i którym można się tylko podporządkować. Autentyczna więź zostaje zastąpiona przez konwencjonalny i oczywiście racjonalny schemat odpowiadający modelowi prezentowanemu przez przemysł kulturalny. „Najbardziej intymne reakcje ludzi są w stosunku do samych ludzi tak urzeczowione, że idea czegoś charakterystycznego istnieje już tylko w postaci skrajnie abstrakcyjnej: personality nie oznacza już nic prócz olśniewających zębów i wolności od spoconych pach oraz emocji”"

Głównym celem dzisiejszej ideologii, którą kapitalistyczne podmioty świadomie i z wygody wybierają, poddając się jej praktycznym zasadom, jest utrzymywanie iluzji, że w osobie biznesowego Odyseusza, określonej przez pożądany zespół cech self-made mana, mamy do czynienia z jedynym i uniwersalnym wzorcem osobowości. Za pomocą tak zideologizowanego języka, o którym Adorno i Horkheimer piszą, że ,nawet najuczciwszy reformator, który w zeszmaconym języku zaleca innowacje, umacnia tylko tę potęgę istniejącego stanu rzeczy, którą chciałby złamać" ${ }^{84}$, nie sposób wyrazić żadnego antagonizmu społecznego poza takim, który swojego wroga eksportuje poza społeczną całość. Kiedy język w ten sposób łączy wielkoprzemysłowca z robotnikiem, tuszując materialistyczną dystynkcję między nimi, spodziewać się możemy najgorszego. Prawda jest taka, że być może jesteśmy na prostej drodze ku temu.

Jacek Kuroń powszechnie znany jako jeden z architektów budowania kapitalizmu w Polsce, cieszący się dużą popularnością i sympatią wśród liberalnych środowisk, pisał przed ponad 20 laty:

\footnotetext{
81 Ibidem, s. 20.

82 M. Horheimer, T.W. Adorno, Dialektyka Oświecenia, s. 69.

83 Ibidem, s. 168.

84 Ibidem, s. 12.
} 
Dziadek opowiadał o strajku powszechnym 1905 roku: - Zawyły syreny i zamarł Sosnowiec. I ja to widziałem, czułem ten zamierający Sosnowiec. Pamiętam pochody pierwszomajowe we Lwowie [...] słyszałem jak wyły syreny. Mam w oczach tłum, który idzie i śpiewa. [...] Stoją patrole kozackie, a oni idą i śpiewają: „Krew naszą długo leją katy”. Dla mnie to jest sacrum. Kiedy wyły syreny na strajkach „Solidarności”, dostawałem dreszczy. [...] Czuję się uczestnikiem rewolucji 1905 roku $^{85}$.

Dziś środowiska dysydenckie z tamtych lat zdają się o tym nie pamiętać lub wolą z rozmysłem teksty Kuronia przemilczeć. Gdyby tej ikonie KOR-u i „Solidarności” wymsknęło się podobne wyznanie w dzisiejszej telewizji, choć od wspomnianych strajków „Solidarności” nie minęło nawet pół wieku, chyba w najlepszym razie wszyscy zbyliby je milczącym politowaniem z szacunku dla weterana, który jak się to często zdarza, żyje jeszcze w rzeczywistości przyćmionej blaskiem światła swojej legendy. W najgorszym przypadku zostałby bezceremonialnie uciszony i uznany za terrorystę. A wszystko to w warunkach dzikiego wyzysku i rynkowej ofensywy w każdej dziedzinie życia, kiedy język oporu klasowego, język walki o pracę, która nie alienuje i pozwala na godny byt, zdaje się być aktualny jak nigdy przedtem.

Dzisiaj jak nigdy dotąd potrzebujemy rozpowszechnionej marksowskiej analizy społecznej, a także być może języka z wczesnych pism autora Kapitału, którym każdy żyjący z własnej pracy będzie mógł wyrazić własną kondycję i zyskać narzędzia do opowiedzenia sobie własnego życia, zamiast usilnie starać się zrozumieć, czym jest jako bezosobowy kapitał ludzki.

Niepodzielne panowanie ideologii kapitalistycznych, ich silna hegemonia ma swoje mocne podstawy w samej strukturze pracy, która separuje wytwórczość od myślenia. Na tym polega alienujący charakter pracy, która przecież powinna być efektem kolektywnej myśli. Kapitalizm, pragnąc zręcznie zabezpieczyć swoją egzystencję, boi się dopuścić klasy uciskane do procesów wymyślania idei i przebierania w różnorodności języków. Mamy obecnie do czynienia z postępującą nieustannie prywatyzacją myślenia jednostek uciskanych, które mogą oddać się wolnej refleksji już tylko we własnych domach, jeżeli jeszcze mają na to siły po całym dniu ciężkiej harówki. Narzucony system jednolitego myślenia wiąże się z poważnym kryzysem polityki, która podlega szyfrowi nic-nie-mówiących zwrotów oraz pozornych i symbolicznych, a nie materialistycznych konfliktów. Polityka sprowadzona do zabiegów reklamowych, sterowana prawidłami marketingu i podporządkowana technologii, przestaje opisywać rzeczywistość i ścierać się z nią, próbując odpowiedzieć na problemy przez nią stawiane; w zamian proponuje koniec historii, życie w świecie kon-

85 J. Kuroń, Wiara i wina, w: idem, Autobiografia, Warszawa 2009, s. 10. 
sumpcji i etyki drobnych egoizmów, które według niej przyczynią się do globalnego postępu ludzkości prowadzonego po torze wytyczonym przez rynek.

\section{Ku nowej świadomości katastroficznej - podsumowanie}

to, co inaczej można by pewnie nazwać również nihilizmem, utrata wiary w możliwość przyszkej europejskiej cywilizacji. Tak, że chociaż byliśmy szczeniakami, fakt powstania Polski byt mniejszej wagi niż ogólna katastrofa epoki, wielka niewiadoma, która była przed nami, przy czym, ponieważ byliśmy młodzi, zuchwali, byla ona niestychanie dla nas o b i e c uj a c a [rozstrzelenie - S.C. $]^{86}$.

Na co dzień możemy obserwować różnorodne dyskursy wyznaczane przez kapitalistyczną ideologię. Słyszeć możemy o kapitalistycznym wyzysku jako konieczności produkcyjnej. Kapitaliści będą nas tu przekonywać, wykorzystując zarazem w sekrecie instytucje państwa dla własnych interesów, że na każdym kroku napotykają stwarzane przez to samo państwo regulacje i utrudnienia w ich przedsiębiorczych i innowacyjnych inicjatywach. Użalać się będą we wszystkich środkach społecznego przekazu, jak szkoda im ich pracowników, którym nie mogą podnieść płacy, bo gospodarka oparta na konkurencji wymusza nieskończoną akumulację. Na początku XX wieku Georges Sorel, nawołując do proletariackiego strajku generalnego, obnażał obłudę takiej argumentacji. Pisał:

Dopóki pracownicy znosili bez sprzeciwu wymagania pracodawców, sądzili, że wola ich panów była całkowicie zdominowana przez konieczność ekonomiczną. Po strajku dostrzegają jednak, że owa konieczność nie jest wcale tak nieuchronna i że jeśli na wolę pana wywrze się silny, oddolny nacisk, wola ta znajdzie sposób na to, by uwolnić się od rzekomych przeszkód ekonomicznych ${ }^{87}$.

Inni kapłani kapitalizmu przekonywać będą, że niepohamowana produktywność jest niezbędna do przetrwania samej cywilizacji. Jest to rozpoznanie ideologiczne, celowo zniekształcające prawdziwe warunki materialne. Pomysł, że moglibyśmy żyć skromniej, ale w systemie o ludzkich i sprawiedliwych stosunkach produkcji, nie postanie w ich głowach. Jeszcze inni ideologowie będą chcieli widzieć źródło kapi-

\footnotetext{
86 A. Wat, Mój wiek, Warszawa 1990, s. 26.

87 G. Sorel, Rozważania o przemocy, Warszawa 2014, s. 66.
} 
talizmu w samej naturze ludzkiej, która dąży do optymalizacji korzyści i wierna jest naturalnemu prawu osiągania zysku dla niego samego. Ignorują jednak to, że ludzka natura jest przecież jedynie historycznym wynikiem stosunków społecznych, organizacji pracy, instytucji, praktyk kulturowych.

Ideologiczne dyskursy są rozmaite i pewnie z różnymi przyjdzie nam się jeszcze spotkać. Wszystkie są dyskursem bezalternatywności, który zastrzega sobie prawo do monopolu. Jest to ich jedyna siła, bo nie zaskarbiają sobie ludzkiej życzliwości ni wiary. Starałem się to ukazać, badając nowoczesną osobowość wzorującą się na postaci Odyseusza, której powszechność przyczyniła się do zrodzenia kapitalizmu i która w tym kapitalizmie się wiecznie odtwarza. Następnie próbowałem przekonać, przywołując prace Althussera, że dzisiaj do takiej podmiotowości i wynikających z niej praktyk interpelowane są przez ideologiczne aparaty państwa wszystkie bez wyjątku jednostki. Ponieważ Žižek i Lacan pomysł interpelacji podmiotów również wykorzystują, posłużyłem się ich teoriami, by zrozumieć, jak ideologia, czyli ideologiczny Wielki Inny, istnieje na mocy interpasywnej wiary, czczego aktu jej wyznania, jakie złożyli między innymi polscy literaci, płacąc stalinizmowi trybut w postaci zaangażowania w zamian za możliwość prywatnej rozkoszy tworzenia.

Człowiek o dobrym smaku nie może traktować zbyt poważnie rezultatów oficjalnego nacisku w dziedzinie kulturalnej, jakkolwiek oklaskuje wiersze, pisze pochlebne recenzje z wystaw malarskich i udaje, że plany ponurej, ciężkiej architektury nowych budynków bardzo trafiają mu do przekonania. Zmienia się całkowicie w czterech ścianach swego domu ${ }^{88}$.

Opis ten jest jak najbardziej aktualny i dzisiaj. Podstawowy problem polega na tym, że w czterech ścianach własnego domu nie powstanie mobilizujący projekt emancypacyjny. To właśnie próbowałem powiedzieć, zwracając uwagę na zjawisko prywatyzowania myślenia będące skutkiem stałego dokręcania śruby wyzysku, który znakomicie wykorzystuje sytuację sztucznego i także ideologicznego podziału na to, co prywatne, i to, co publiczne, na co wskazywał też Althusser, powołując się na włoskiego filozofa Antonio Gramsciego. Skoro zaś warunki konieczne do kolektywnej myśli systematycznie usuwane są przez same warunki produkcji, wydłużający się do granic możliwości czas oderwanej od idei pracy, trudno wyobrazić sobie, by strategia oporu mogła zostać wynaleziona lub przyswojona przez samą klasę uciskaną. Tym bardziej że dokonało się w ostatnich dziesięcioleciach rozbicie jej wspólnoty i jedności. Toteż jedyną nadzieją, jaka może wydać się ocalająca, jest szybkie uzyskanie powszechnej świadomości nadciągającego końca. Końca, który może przekroczyć, jak przed kilkudziesięcioma laty, najśmielsze katastroficzne proroctwa. Być może

88 C. Miłosz, Zniewolony umyst, s. 59. 
jedyna nadzieja tkwi w deterministycznej sentencji: im gorzej, tym lepiej. Póki co zachowujemy się tak, ,jak Chaplin w Goraczce złota, który krzątając się po swojej chacie, nie podejrzewa, że wisi ona na skraju przepaści" ${ }^{89}$. Może więc potrzeba nam nowego katastrofizmu, świadomości nowej nadciągającej zagłady, którą sobie szykujemy, by tuż przed osiągnięciem dna, od którego nie będzie powrotu, wybić się i wyrwać z prywatnej celi cynizmu, złączyć siły myśli i pracy rąk do stworzenia świata równych sobie.

\title{
HOW PREVAILING IDEOLOGY PREVENTS SOCIAL CHANGE
}

Keywords: ideology, capitalism, subject, Enlightenment, interpellation, Karl Marx, Teodor Adorno, Max Horkheimer, Louis Althusser, Jacques Lacan, Slavoj Žižek, instrumental reason, class, practice

\begin{abstract}
The work tries to analyze how ideology, understood in agreement with the marxist tradition, inhibits any structural social change. The first part of the work is devoted to a description of the capitalist reality in which the well known ideology has been created. In the next chapter, aiming at systematization of the notion of ideology, the Karl Mannheim's theory of ideology is presented. The main goal of the remaining part of the work is to show how the rise of the modern universal capitalist subject has erased from the view the class resistance against impersonal forces of the global market. To better present this, in the following chapters invoked are the works of the Frankfurt school of Theodore Adorno and Max Horkheimer, of the french structuralists Luis Althusser and Jacques Lacane as well as works of Slavoj Zizek and Peter Sloeterdijk, which concentrate on the modern cynic attitude. For the historic example of this phenomenon taken is the described by Czesław Miłosz reality of the stalinist regime, in which the conformist attitude does not significantly differ from the known attitude widespread in the capitalist reality. Pointing out this similarity is the main idea of the present work.
\end{abstract}

89 Ibidem, s. 31. 